\title{
Indian Ocean Dipole and El Niño/Southern Oscillation impacts on regional chlorophyll anomalies in the Indian Ocean
}

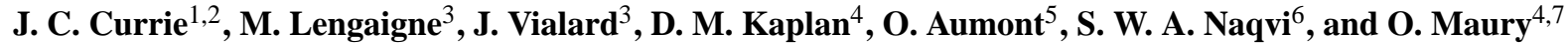 \\ ${ }^{1}$ Biological Sciences Department, Marine Research Institute, University of Cape Town, Cape Town, South Africa \\ ${ }^{2}$ Egagasini Offshore Node, South African Environmental Observation Network, Cape Town, South Africa \\ ${ }^{3}$ Institut de Recherche pour le Développement, Laboratoire d'Océanographie et du Climat: Expérimentation et Approches \\ Numériques, UMR 7617, Université Pierre et Marie Curie, Paris, France \\ ${ }^{4}$ Institut de Recherche pour le Développement, UMR212 EME (IRD, IFREMER, Université Montpellier II), Sète cedex, \\ France \\ ${ }^{5}$ Institut de Recherche pour le Développement, Laboratoire de Physique des Océans, UMR6523, Brest, France \\ ${ }^{6}$ CSIR-National Institute of Oceanography, Dona Paula, Goa, India \\ ${ }^{7}$ Department of Oceanography, Marine Research Institute, University of Cape Town, Cape Town, South Africa
}

Correspondence to: J. C. Currie (jockcurrie@gmail.com)

Received: 25 February 2013 - Published in Biogeosciences Discuss.: 26 March 2013

Revised: 3 September 2013 - Accepted: 4 September 2013 - Published: 24 October 2013

\begin{abstract}
The Indian Ocean Dipole (IOD) and the El Niño/Southern Oscillation (ENSO) are independent climate modes, which frequently co-occur, driving significant interannual changes within the Indian Ocean. We use a fourdecade hindcast from a coupled biophysical ocean general circulation model, to disentangle patterns of chlorophyll anomalies driven by these two climate modes. Comparisons with remotely sensed records show that the simulation competently reproduces the chlorophyll seasonal cycle, as well as open-ocean anomalies during the 1997/1998 ENSO and IOD event. Results suggest that anomalous surface and euphoticlayer chlorophyll blooms in the eastern equatorial Indian Ocean in fall, and southern Bay of Bengal in winter, are primarily related to IOD forcing. A negative influence of IOD on chlorophyll concentrations is shown in a region around the southern tip of India in fall. IOD also depresses depthintegrated chlorophyll in the $5-10^{\circ} \mathrm{S}$ thermocline ridge region, yet the signal is negligible in surface chlorophyll. The only investigated region where ENSO has a greater influence on chlorophyll than does IOD, is in the Somalia upwelling region, where it causes a decrease in fall and winter chlorophyll by reducing local upwelling winds. Yet unlike most other regions examined, the combined explanatory power of IOD and ENSO in predicting depth-integrated chlorophyll anomalies is relatively low in this region, suggestive that other
\end{abstract}

drivers are important there. We show that the chlorophyll impact of climate indices is frequently asymmetric, with a general tendency for larger positive than negative chlorophyll anomalies. Our results suggest that ENSO and IOD cause significant and predictable regional re-organisation of chlorophyll via their influence on near-surface oceanography. Resolving the details of these effects should improve our understanding, and eventually gain predictability, of interannual changes in Indian Ocean productivity, fisheries, ecosystems and carbon budgets.

\section{Introduction}

The El Niño/Southern Oscillation (ENSO) is well-known as a dominant mode of interannual climate variability that develops from air-sea interactions in the tropical Pacific, but affects weather patterns globally (McPhaden et al., 2006). During an El Niño, air-sea interactions promote the growth of positive sea surface temperature (SST) and sea level anomalies in the central and eastern Pacific and corresponding negative anomalies in the western Pacific. Changes in thermocline depth and surface ocean dynamics and thermodynamics are driven by anomalous atmospheric conditions, most notably westerly surface winds in the central and western ocean 
(Wang and Fiedler, 2006). The SST expression of ENSO events generally peak between November and January (Trenberth, 1997). Teleconnections associated with El Niño result in an overall warming of the Indian Ocean (Klein et al., 1999; Murtugudde and Busalacchi, 1999; Xie et al., 2009), due to changing cloud cover and wind patterns that relate to changes in ascending and descending branches of the Walker circulation (Du et al., 2009; Reason et al., 2000; Venzke et al., 2000). In turn, such physical perturbations can affect the biology in local and distant oceans (Ménard et al., 2007; Spencer et al., 2000; Vinueza et al., 2006). Applying empirical orthogonal function (EOF) analyses to $4 \mathrm{yr}$ of global SeaWiFS data, which provide an estimate of surface phytoplankton biomass, Yoder and Kennelly (2003) identified two interannual modes of variability in surface chlorophyll, both of which they ascribed to ENSO control.

Whereas the Indian Ocean was previously considered to be largely passive to the interannual forcing of ENSO, it was shown in the late 1990s to exhibit its own mode of interannual variability (Murtugudde and Busalacchi, 1999; Saji et al., 1999; Webster et al., 1999), which impacts both local and remote regions (Izumo et al., 2010; Yamagata et al., 2004). This mode is commonly referred to as the Indian Ocean Dipole (IOD) mode, even though contention exists over whether it should be referred to as a 'dipole' (BaqueroBernal et al., 2002; Hastenrath, 2002). A positive event is associated with anomalous easterly winds in the central Indian Ocean and cold SST anomalies off the south and west coasts of Java and Sumatra. These two anomalies enhance each other in a positive feedback loop (Reverdin et al., 1986; Webster et al., 1999) similar to the Bjerknes feedback critical to ENSO events (Bjerknes, 1969). The anomalous easterly winds raise the thermocline in the eastern part of the basin and, together with off-equatorial Rossby wave responses, deepen the thermocline and warm the SST in the western Indian Ocean, resulting in characteristic zonal anomaly patterns in sea level height, as well as surface and subsurface temperature structures (e.g. Feng and Meyers, 2003; Murtugudde et al., 2004; Rao et al., 2002). Thermocline anomalies typically initiate earlier and persist longer than the surface temperature signals (Horii et al., 2008). Negative IOD events feature opposite anomalies over similar regions (Meyers et al., 2007; Vinayachandran et al., 2002). Like ENSO, IOD events are phase-locked to the seasonal cycle and develop during boreal spring, peak in about October, and decay by the end of the calendar year. IOD events are commonly triggered by El Niño events and frequently co-occur with them, yet they also occur independently and thus are considered an independent climate mode (Annamalai et al., 2003; Meyers et al., 2007; Song et al., 2007; Yamagata et al., 2004).

Compared to the impacts on the physical structure of the Indian Ocean, the biological consequences of IOD events have received far less attention, despite their potential importance to ecosystems, fishery resources and carbon sequestra- tion. After the launch of SeaWiFS and with recent progression of coupled biophysical ocean models, the fields required to investigate seasonal and interannual variability at basin scales have become increasingly accessible (e.g. Rodgers et al., 2008; Wiggert et al., 2005, 2006, 2009; Yoder and Kennelly, 2003). Satellite coverage of chlorophyll concentrations has allowed investigation of the most recent ENSO/IOD events (e.g. Iskandar et al., 2009; Murtugudde et al., 1999; Wiggert et al., 2009). The intense 1997 positive IOD/El Niño event was characterised by a strong phytoplankton bloom in the eastern equatorial Indian Ocean; an area which is normally characterised by low productivity (Murtugudde et al., 1999; Susanto and Marra, 2005). The upwelling of cool, nutrient-rich water and associated biological productivity had a detrimental impact on coral reefs in a large area off the coast of Indonesia (Abram et al., 2003, 2004; van Woesik, 2004). Other documented impacts of the 1997 event included a decrease of surface chlorophyll in the Arabian Sea (Sarma, 2006) attributed to anomalous northeasterly winds, as well as a bloom in the southeastern Bay of Bengal, owing to anomalous Ekman pumping in this region (Vinayachandran and Mathew, 2003). Although similar blooms developed in the eastern Indian Ocean during the 2006 IOD (Iskandar et al., 2009), Wiggert et al. (2009) showed that the biological responses to the 1997 event were of greater intensity, with more persistent and stronger positive anomalies spreading further west than in 2006, due to a reversal (as opposed to weakening) of the Wyrtki jet in the boreal fall intermonsoon. In addition, their results showed that the bloom in the southeastern Bay of Bengal and the low chlorophyll anomaly in the Arabian Sea observed during 1997 developed only weakly during the less severe 2006 event.

Wiggert et al. (2009) made use of a remote sensing-based algorithm to make a first assessment of basin-wide primary production (NPP) anomalies caused by the 1997 and 2006 IOD/El Niño events. These events appeared to have had a minimal effect on the net NPP averaged over the event periods and entire Indian Ocean, due to compensating responses among different regions. There is however a profound redistribution of the carbon uptake, with a large NPP increase in the eastern Indian Ocean, roughly balanced by a decrease in western regions. While the two events did not significantly impact surface chlorophyll in the southwestern Indian Ocean, the region did exhibit negative NPP anomalies, due to anomalously deep thermocline depths (Wiggert et al., 2009). NPP anomalies varied considerably, depending on the event considered: positive NPP anomalies in the eastern Indian Ocean varied between 45 and $13 \%$; negative anomalies in the southwestern Indian Ocean varied between -20 and $-8 \%$; while the Arabian Sea experienced NPP changes of -9 and $+15 \%$ during the 1997 and 2006 events respectively. These contrasts reveal the changing nature of biological impacts among different events.

Although SeaWiFS now provides over a decade of data at high spatial and temporal resolution, this period is still 
restrictive in addressing interannual or long-term changes. Only two clear positive IODs have developed during the SeaWiFS era, which represents a limited sample size and does not allow investigation of the full spectrum of possible IOD/ENSO configurations (e.g. Meyers et al., 2007; Song et al., 2008). Moreover, problems with remotely sensed chlorophyll in some oligotrophic regions have been noted (Claustre et al., 2002; Dandonneau et al., 2003) and sensors potentially miss a proportion of depth-integrated chlorophyll when chlorophyll maxima are deeper than the first optical depth or "penetration depth" ( $\sim 20 \mathrm{~m}$; Gordon and McCluney, 1975). Fortunately, longer-term biogeochemical and biological hindcasts from coupled biophysical models are increasingly capable of revealing subsurface processes not captured by satellites, and are resolving seasonal and interannual variability to an ever-improving degree (e.g. Koné et al., 2009; Maury, 2010; Rodgers et al., 2008; Wiggert et al., 2006).

This study aims to investigate the interannual changes in chlorophyll caused by IOD- and ENSO-induced changes to the physical ocean. We make use of a four-decade hindcast from the coupled biophysical general circulation model, NEMO-PISCES, to separate the respective contributions of ENSO and IOD to surface and vertically integrated chlorophyll anomalies in the Indian Ocean. Focusing predominantly on the biological response, we also assess responses in SST, thermocline depth and surface winds to explore the physical processes driving the variability in chlorophyll. An improved understanding of such dynamics will aid constructive hypotheses about, and interpretations of, ecosystem links to climate variability and thereby contribute towards attaining predictability of impacts from similar events in future.

The paper is structured as follows. Section 2 describes the data and methods used. A brief comparison between the modelled surface chlorophyll and SeaWiFS outputs is provided for the Indian Ocean in Sect. 3. Section 4 describes the influences of IOD and ENSO on thermal and chlorophyll responses in surface waters of the Indian Ocean. Section 5 summarises our main findings and discusses them in the context of relevant literature.

\section{Data and methods}

\subsection{Observed data sets}

Chlorophyll $a$ (Chl $a$ ) concentrations were obtained from the European Space Agency's GlobColour project. We used a remotely sensed level 3 (binned and mapped) $1^{\circ}$ and monthly resolution $\mathrm{Chl} a$ data set, which is derived using standard case 1 water algorithms (Morel and Maritorena, 2001; O'Reilly et al., 1998). This data set is a merged product from three sensors (SeaWiFS, MERIS, and MODIS-Aqua), which has approximately twice the mean global coverage and lower uncertainties in retrieved variables compared to data from individual sensors (Maritorena et al., 2010). While small systematic differences exist among the products of individual sensors, the large-scale $\mathrm{Chl} a$ distributions produced by these major ocean colour missions are consistent over a wide range of conditions (Djavidnia et al., 2010; Morel et al., 2007).

\subsection{Ocean model and forcing data sets}

Hindcasts from an ocean general circulation model (OGCM), coupled to a biogeochemical model were used to investigate interannual anomalies of chlorophyll and physical variables. The simulation used in this paper has been detailed in Koné et al. (2009), so we describe only its main features here. The NEMO ocean configuration was built from the OPA (Ocean PArallelise) version 8.2 ocean model (Madec et al., 1998), coupled to the dynamic-thermodynamic Louvainla-Neuve sea ice model (LIM; Timmermann et al., 2005). This $0.5^{\circ}$ configuration (known as ORCA05-LIM; cell size $\sim 50 \mathrm{~km}$ in the tropics) has 30 vertical levels, of which 20 are concentrated in the upper $500 \mathrm{~m}$; their thickness increasing from $10 \mathrm{~m}$ near the surface to $500 \mathrm{~m}$ at depth. Density was computed from potential temperature, salinity and pressure using the equation of state by Jackett and Mcdougall (1995). Vertical mixing was parameterised from a turbulence closure scheme based on a prognostic vertical turbulent kinetic equation, which has been shown to perform well in the tropics (Blanke and Delecluse, 1993). Simulated lateral mixing acts along isopycnal surfaces, with a Laplacian operator and $200 \mathrm{~m}^{2} \mathrm{~s}^{-1}$ constant isopycnal diffusion coefficient (Lengaigne et al., 2003). Penetration of short-wave fluxes into the ocean was based on a single exponential profile (Paulson and Simpson, 1977), corresponding to oligotrophic water (attenuation depth of $23 \mathrm{~m}$ ). No-slip boundary conditions were applied at the coastlines.

The OGCM has been used extensively in an uncoupled mode (Cravatte et al., 2007; Lengaigne et al., 2002) and coupled with an atmospheric model (Lengaigne et al., 2006; Lengaigne and Vecchi, 2010), using various forcing strategies. It has been shown to accurately simulate the vertical structure of equatorial temperature and currents (Vialard et al., 2001), as well as the interannual variations of heat content in the Pacific Ocean (Lengaigne et al., 2012). In addition, the model compared well with interannual sea level data from satellite altimetry and tide gauges in the tropical Indian and Pacific oceans (Nidheesh et al., 2012). Keerthi et al. (2013) show that the model simulates interannual variability of the mixed layer depth relatively well in the Indian Ocean, with similar spatial patterns and reasonable phase agreement compared to estimates from in situ data.

The physical model was coupled with the Pelagic Interaction Scheme for Carbon and Ecosystem Studies biogeochemical model (PISCES; Aumont et al., 2008; Aumont and Bopp, 2006). A concise overview of PISCES is provided here; a full description of the model, including model parameters 
and brief validation of results is available in the supplementary material of Aumont and Bopp (2006). The biogeochemical model has 24 compartments, which include two sizes of sinking particles and four "living" biological pools, represented by two phytoplankton (nano-phytoplankton and diatoms) and two zooplankton (microzooplankton and mesozooplankton) size classes. Phytoplankton growth is limited by five nutrients: $\mathrm{NO}_{3}, \mathrm{NH}_{4}, \mathrm{PO}_{4}, \mathrm{SiO}_{4}$, and $\mathrm{Fe}$. The ratios among $\mathrm{C}, \mathrm{N}$, and $\mathrm{P}$ are kept constant for the "living" compartments, at values proposed by Takahashi et al. (1985). The internal $\mathrm{Fe}$ contents of both phytoplankton groups and Si contents of diatoms are prognostically simulated as a function of ambient concentrations in nutrients and light level. Details on the red-green-blue model by which light penetration profiles are calculated, are given in Lengaigne et al. (2007). The $\mathrm{Chl} / \mathrm{C}$ ratio is modelled using a modified version of the photo-adaptation model by Geider et al. (1998). Ratios of elements within zooplankton compartments are kept constant. Manuals for NEMO and PISCES are available online (http: //www.nemo-ocean.eu/About-NEMO/Reference-manuals).

The physical model was initialised from rest with salinity and temperature climatologies of the World Ocean Atlas 2001 (Boyer et al., 2005). The biogeochemical model was initialised from outputs of the simulation described by Aumont and Bopp (2006). Thereafter a 7 yr spin-up period was performed on the coupled model and the simulation was run over the period 1958-2001. Surface boundary conditions were applied to the OGCM as follows: daily surface wind stresses were specified from the ERA40 re-analysis (Uppala et al., 2005). Radiation fluxes were based on the CORE v1 data set, using the International Satellite Cloud Climatology Project's radiation product (Zhang et al., 2004), available from 1984 onwards. Prior to 1984 a climatology of the radiation fluxes was imposed, which leads to better results than the use of reanalysis data. Precipitation was taken from the Climate Prediction Center Merged Analysis of Precipitation (CMAP; Xie and Arkin, 1997), available from 1979 onwards, while a CMAP climatology was applied before then. Evaporation and turbulent heat fluxes were computed using empirical bulk formulae by Goosse (1997), which employed ERA40 daily wind speed and air temperatures, as well as climatological relative humidity fields from Trenberth et al. (1989). To avoid artificial model drift, sea surface salinity was restored towards monthly mean climatological values from the World Ocean Atlas (Boyer et al., 2005), with a timescale of 300 days for a typical $50 \mathrm{~m}$-thick mixed layer. Outputs were generated on a temporal resolution of 5 days.

Using the same model, Koné et al. (2009) show that Indian Ocean features of the seasonal chlorophyll cycle compare reasonably well with SeaWiFS, including the timing of bloom onsets. In addition, recognised biogeochemical provinces are reproduced in most of the Arabian Sea, Bay of Bengal and in the convergence zone south of the Equator (Koné et al., 2009). In our analyses, the first $3 \mathrm{yr}$ of the simu- lation (1958-1960) were omitted, in order to avoid potential spin-up effects.

\subsection{Methodology}

The depth of the $20^{\circ} \mathrm{C}$ isotherm (D20) was estimated by linear interpolation of temperature between model levels. Chlorophyll concentrations were calculated as the sum of chlorophyll from the two phytoplankton size classes (diatoms and nano-phytoplankton). Surface chlorophyll concentrations (denoted by $S \mathrm{Chl}$; units of $\mathrm{mg} \mathrm{m}^{-3}$ ) were averaged over the upper two layers (i.e. $20 \mathrm{~m}$ depth) for comparison with SeaWiFS. The euphotic zone was estimated from the photosynthetically available radiation (PAR) outputs, as the depth where PAR was $1 \%$ of the surface value. The depth-integrated chlorophyll was then computed over the euphotic zone, and is referred to as integrated chlorophyll or IChl hereafter (units of $\mathrm{mg} \mathrm{m}^{-2}$ ).

Interannual anomalies for all fields were computed from monthly time series as the remainder after removal of their mean seasonal cycle and "long-term trend" components by the seasonal decomposition of time series by loess function (STL; Cleveland et al., 1990), in R programming language (R Development Core Team, 2011). The trend component was estimated by a degree-one polynomial fitted over a $7 \mathrm{yr}$ loess window and serves to remove longer-term variability on the order of decades or greater. All analyses were performed on these anomalies, except for the seasonal comparison of average surface chlorophyll between model and SeaWiFS (Fig. 1). To represent the interannual signals associated with IOD and ENSO, standard indices were used: the Pacific ENSO signal was represented by averaged SST anomalies over the Niño3.4 region during NovemberJanuary (Trenberth, 1997). The IOD was characterised by the dipole mode index (DMI), computed as the difference between SST anomalies in the western and eastern equatorial Indian Ocean during September-November (Saji et al., 1999). Both climate indices were standardised to unit variance. The geographical limits used for calculation of the climate indices are summarised in Table 1. Geographical regions in which the physical and biological variability was investigated in more detail are also listed in Table 1 and shown in Figs. 3 and 6.

One of the principal objectives of this study was to separate the impacts of ENSO and IOD on Indian Ocean chlorophyll and physical variables. Because of the frequent cooccurrence of IOD and ENSO events and the resultant correlation between their indices ( $\sim 0.53$; Yamagata et al., 2004), it is difficult to isolate signals associated with each of these climate modes using regular regression. We therefore employed partial regression techniques to separate the impacts of IOD and ENSO, as has previously been applied to separate their signals in physical fields (Keerthi et al., 2012). Partial regression estimates the impact of one variable on another, after having removed the impact of a third variable 


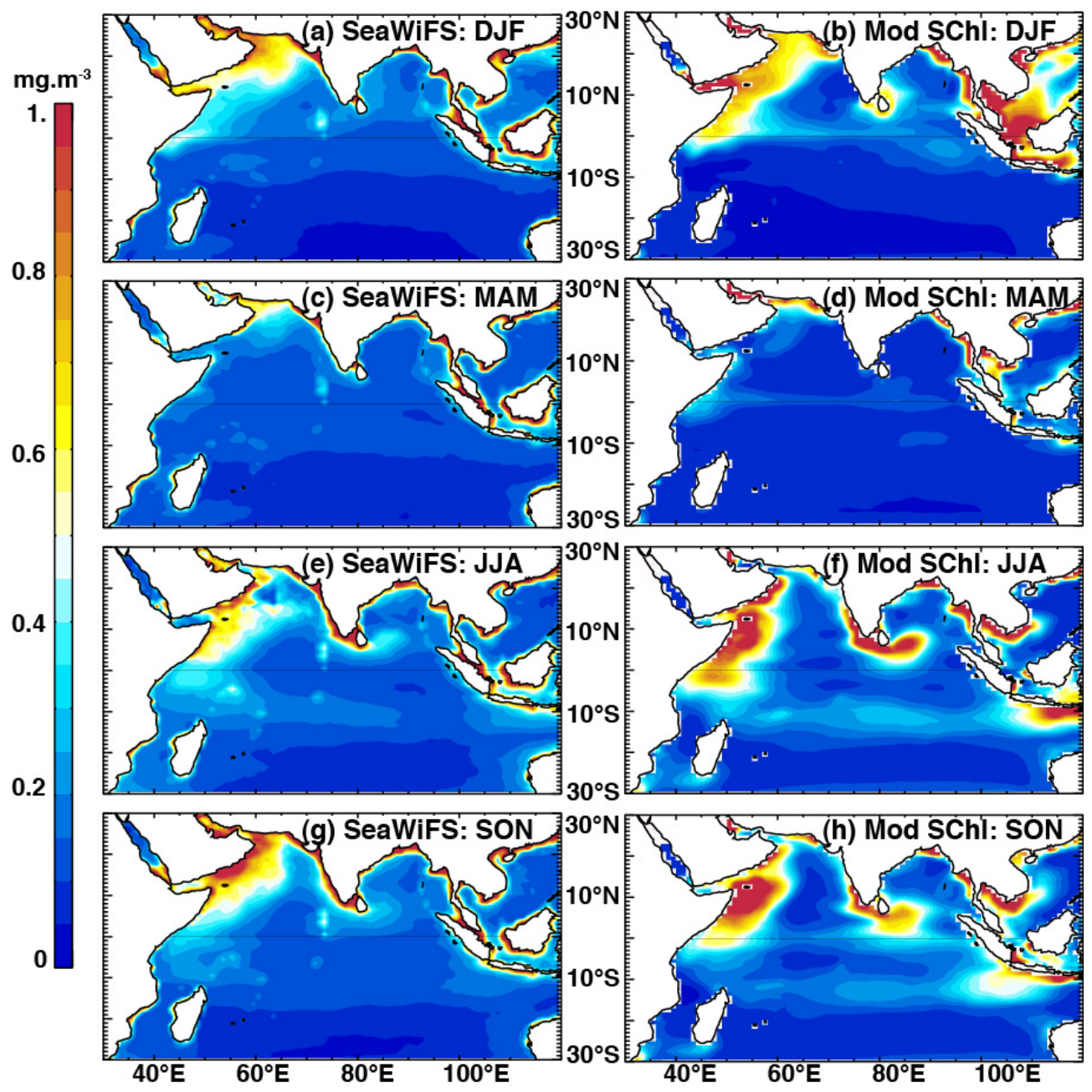

Fig. 1. Seasonal evolution of average SChl patterns from SeaWiFS satellite estimates (left panels) and model outputs (right panels). Seasons are represented as December-February (DJF), March-May (MAM), June-August (JJA) and September-November (SON). The seasonal cycle was calculated over the 1998-2009 period for observations and 1990-2001 for the model (see Sect. 3 for details).

Table 1. Description and coordinate boundaries of the areas used in the calculation of climate indices and of regions investigated in greater detail. These regions of interest are also indicated in Figs. 3 and 6.

\begin{tabular}{llll}
\hline Abbreviation & Description & Latitudes & Longitudes \\
\hline Niño3.4 & Niño3.4 region in the Pacific Ocean & $5^{\circ} \mathrm{N}-5^{\circ} \mathrm{S}$ & $120-170^{\circ} \mathrm{W}$ \\
wDMI & western Dipole Mode Index region & $10^{\circ} \mathrm{N}-10^{\circ} \mathrm{S}$ & $50-70^{\circ} \mathrm{E}$ \\
eDMI & eastern Dipole Mode Index region & $0-10^{\circ} \mathrm{S}$ & $90-110^{\circ} \mathrm{E}$ \\
EEIO & eastern equatorial Indian Ocean; same as eDMI & $0-10^{\circ} \mathrm{S}$ & $90-110^{\circ} \mathrm{E}$ \\
wSCTR & western Seychelles-Chagos thermocline ridge & $5-15^{\circ} \mathrm{S}$ & $60-90^{\circ} \mathrm{E}$ \\
SBoB & southern Bay of Bengal & $0-10^{\circ} \mathrm{N}$ & $85-100^{\circ} \mathrm{E}$ \\
STI & ocean around the southern tip of India & $2-9^{\circ} \mathrm{N}$ & $70-85^{\circ} \mathrm{E}$ \\
WAS & western Arabian Sea & $5-15^{\circ} \mathrm{N}$ & $50-63^{\circ} \mathrm{E}$ \\
TIO & tropical Indian Ocean & $25^{\circ} \mathrm{N}-25^{\circ} \mathrm{S}$ & $40-110^{\circ} \mathrm{E}$ \\
\hline
\end{tabular}

on both. As an example, computation of the partial regression between a time series of chlorophyll anomalies (CHL) and the IOD index (DMI), independently of the ENSO in- dex (Niño3.4) required computation of three separate linear regressions:

$\mathrm{CHL}=a \times \mathrm{Niño} .4+r . \mathrm{CHL}_{-\mathrm{E}}$, 
$\mathrm{DMI}=b \times$ Niño3.4 $+r$. DMI-E,

$r . \mathrm{CHL}_{-\mathrm{E}}=c \times r \cdot \mathrm{DMI}_{-\mathrm{E}}+r \cdot \mathrm{CHL}_{-\mathrm{E}-\mathrm{I}} \cdot$

CHL and DMI were regressed on the Niño3.4 index (Eqs. 1, 2) to provide residuals that were free of linear ENSO signals (denoted $r$.CHL-E and $r$.DMI-E respectively). In a third computation, these residuals were in turn regressed (Eq. 3) to provide an estimate of CHL variability that was linearly related to IOD, without the effect of ENSO. The ${ }_{-E}$ and $-\mathrm{I}$ subscript notations indicate residuals that have had their ENSO or IOD signals removed respectively. Letters $a, b$ and $c$ represent regression coefficients that estimate the effect of the climate indices on the chlorophyll anomalies (or climate index in Eqs. 2 and 5). A visual example of the removal of the linear climate mode signals from (in this case) CHL anomalies is provided in the supplementary material (Fig. S1). As climate indices (DMI and Niño3.4) were transformed to have zero mean and unit variance, these regression coefficients correspond to the change in the response variable (e.g. $\mathrm{mg} \mathrm{m}^{-3}$ for $S \mathrm{Chl}$ ) that would be expected from a climate anomaly of magnitude 1 .

The reciprocal partial regressions were also performed, removing the DMI signal from CHL (Eq. 4) and Niño3.4 (Eq. 5), before regressing their residuals to obtain an estimate of CHL variability that was related to ENSO without the effect of IOD (Eq. 6):

$$
\mathrm{CHL}=a \times \mathrm{DMI}+r \cdot \mathrm{CHL}_{-\mathrm{I}} \text {, }
$$

Niño3.4 $=b \times \mathrm{DMI}+r$ Niño3.4_I,

$r . \mathrm{CHL}_{-\mathrm{I}}=c \times r . \mathrm{Niño} 3.4_{-\mathrm{I}}+r . \mathrm{CHL}-\mathrm{I}-\mathrm{E}$.

Having removed the influence of DMI, the proportion of (in this case) CHL variance, explained purely by Niño3.4 ( $V . \mathrm{CHL}_{\mathrm{Niño3.4}}$ ), was estimated as the difference between residual variances from Eqs. (4) and (6), relative to the variance of the original CHL anomalies:

$V . \mathrm{CHL}_{\mathrm{Niño} 3.4}=\frac{\operatorname{var}\left(r . \mathrm{CHL}_{-\mathrm{I}}\right)-\operatorname{var}\left(r . \mathrm{CHL}_{-\mathrm{I}-\mathrm{E})}\right.}{\operatorname{var}(\mathrm{CHL})}$.

Similarly, the variance explained purely by DMI was calculated as the difference between residual variances from Eqs. (1) and (3), relative to the variance of (in this case) CHL (not shown). Chlorophyll anomalies were substituted with D20 and SST anomalies in the above equations to compute the partial regressions for those variables respectively.
To complement the partial regression results, partial correlations between anomaly fields and DMI/ENSO indices were calculated as in Yamagata et al. (2004). When interpreting the results of partial regressions and partial correlations, one has to bear in mind that a proportion of joint variability, which is related to both IOD and ENSO, is removed from the result. Put differently, the explanatory power of "pure" IOD and "pure" ENSO signals from partial regressions will frequently add up to less than when they are combined in a multiple regression.

\section{SeaWiFS and model comparison}

Comparison of the model outputs and SeaWiFS is complicated by the fact that they overlap during a relatively short period of $4 \mathrm{yr}$ (and 4 months). We chose to use a longer $10 \mathrm{yr}$ period to provide a robust estimate of the seasonal climatology in our comparisons. These periods were selected to maximise the overlap between the model and observations: 1998-2009 for SeaWiFS and 1990-2001 for the model. Using the common 1998-2001 period to estimate the climatology provided very similar results (not shown).

Estimates of surface chlorophyll from model outputs and SeaWiFS showed a similar picture overall, though the magnitude and spatial extent of simulated phytoplankton blooms are to some degree overestimated, while intense coastal blooms in SeaWiFS records are lacking in the model. Figure 1 shows the mean seasonal cycle of surface chlorophyll in the model and observations. During the northeast monsoon in boreal winter, elevated SChl concentrations are found over the northwestern part of the Arabian Sea and the northern Bay of Bengal (BoB; Fig. 1a, b). Oligotrophic conditions prevail in the southeastern Arabian Sea, central BoB and in the Southern Hemisphere. These features are relatively well reproduced by the model, although the intensity of the bloom is overestimated along Somalia and around Sri Lanka (Fig. 1b). The spring intermonsoon is characterised for both model and observations by oligotrophic conditions and reduced chlorophyll in most of the Indian Ocean basin (Fig. 1c, d). During the summer/southwest monsoon and fall intermonsoon (Fig. 1e-h), the model correctly simulates phytoplankton blooms along the coasts of Somalia and the Arabian Peninsula, at the southern tip of India, around Sri Lanka, along the Seychelles-Chagos thermocline ridge between 5 and $15^{\circ} \mathrm{S}$, and in the southeastern Indian Ocean. The amplitude of these blooms is frequently overestimated in oceanic regions compared to SeaWiFS, whereas the chlorophyll values are notably underestimated in the central Arabian Sea, resulting in an exaggerated gradient from the western continental margin to the interior of the basin (Fig. 1e-h).

A more detailed comparison of the seasonal evolution of the modelled and observed surface chlorophyll in the Indian Ocean are provided in Koné et al. (2009). Using the same methods as Lévy et al. (2007), their study demonstrates that 

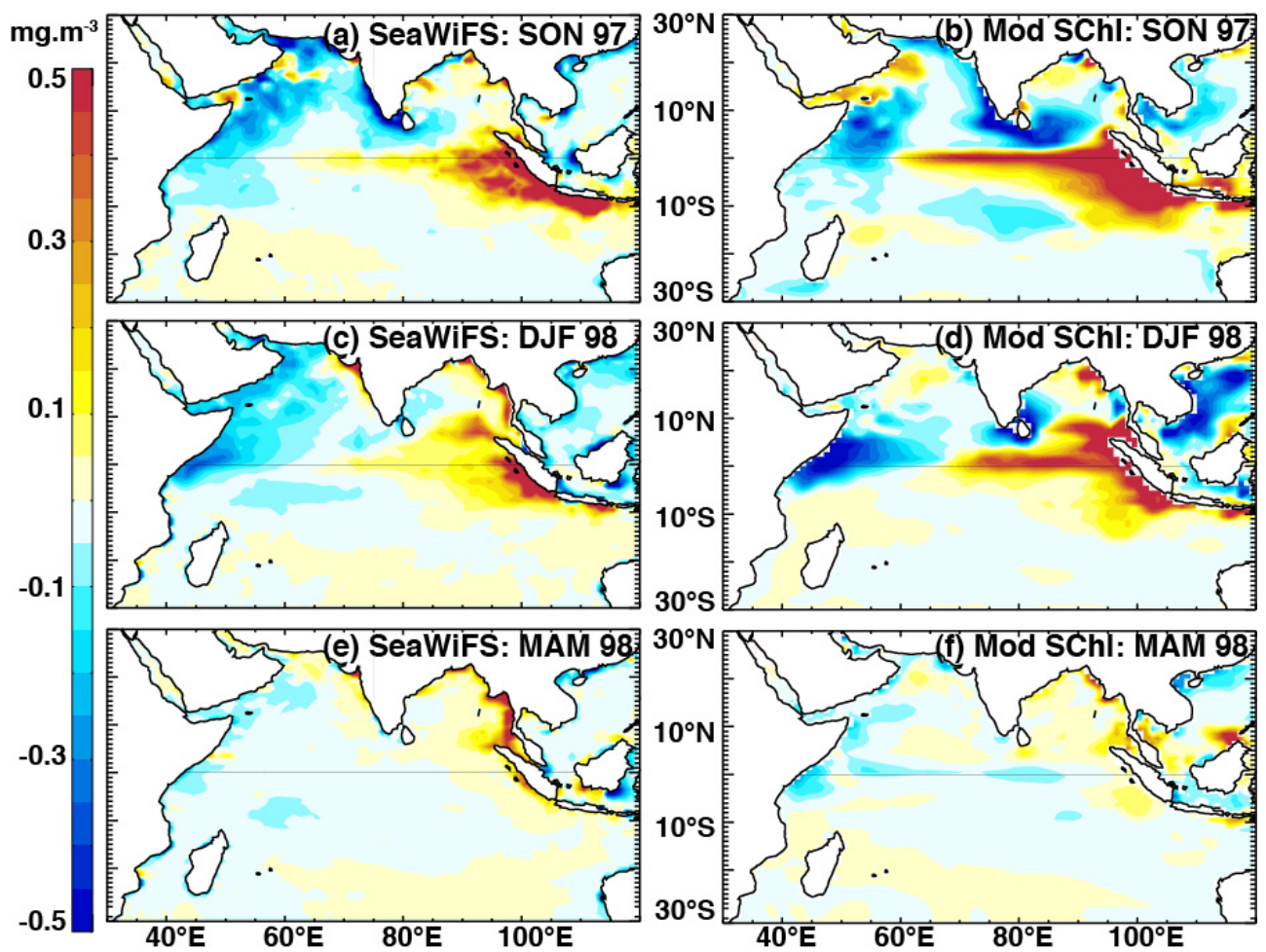

Fig. 2. Anomalies of SChl during the $1997 / 1998$ event from SeaWiFS satellite estimates (left panels) and model outputs (right panels). Anomalies were calculated with respect to a 1998-2009 climatology for SeaWiFS and a 1990-2001 climatology for the model (see Sect. 3 for details). Season abbreviations as in Fig. 1.

the model identified similar biogeographic provinces to SeaWiFS data, specifically in most of the Arabian Sea, Bay of Bengal and in the convergence zone regions south of the Equator. These biogeochemical provinces were based on the cumulated increase in chlorophyll of summer or winter phytoplankton blooms, as well as the timing of these bloom onsets.

Anomalies during the 1997-1998 ENSO/positive IOD event display similar regional-scale features in SeaWiFS and the model (Fig. 2). The intense positive anomalies along the coastline of Sumatra and Java in fall were well simulated, although their intensity and westward equatorial extension are overestimated by the model (Fig. 2a, b). Positive anomalies persist throughout boreal winter in the eastern equatorial Indian Ocean in both SeaWiFS and the model (Fig. 2c, d). The model correctly simulates a chlorophyll bloom in the southeastern Bay of Bengal in winter (north of $4^{\circ} \mathrm{N}$ and extending to $85^{\circ} \mathrm{E}$ ). In addition, the chlorophyll decrease along the western coast and southern tip of India in fall is reasonably well captured by the model, although slightly overestimated in extent. The northern-central Arabian Sea shows some inconsistency between the model's (positive) and SeaWiFS' anomalies (negative) during the 1997/1998 winter season (Fig. 2c, d), indicative that the simulation may be lacking some dynamics in this area. However, the chlorophyll de- creases in the western Arabian Sea in fall and their persistence along the Somalia coast in winter seem to be correctly predicted by the model.

Attributing causes to model-data differences is not an easy task since separating forcing errors and physical versus biogeochemical-ecosystem model deficiencies are beyond the scope of this study. Although zooplankton fields are simulated in the model, upper trophic levels are not included and lacking ecosystem dynamics could account for some of the model-SeaWiFS differences. The signal to noise ratio of satellite-derived chlorophyll is an issue that is not addressed here (Ballabrera-Poy et al., 2003) and neither are regionally specific ecosystem processes such as the dependence on aeolian iron supply (Wiggert and Murtugudde, 2007; Behrenfeld et al., 2009). In general, broad chlorophyll patterns correspond in the model and SeaWiFS, despite more localised differences, mainly in coastal regions. As a result, we focus our interpretations and discussions of model results below on regional-scale $(>500 \mathrm{~km}$ ) patterns in the open ocean. 


\section{Influence of IOD and ENSO in the Indian Ocean}

\subsection{Physical response}

Investigation of surface temperature and thermocline depth anomalies provides an overview of regional variability in the physical response of the surface ocean to interannual forcing. Figure 3 highlights the regions of strong interannual variability of the $20^{\circ} \mathrm{C}$ isotherm depth (D20; a commonly used proxy of thermocline depth in tropical waters) and SST. Regions of pronounced thermocline depth and SST variability include the Eastern Equatorial Indian Ocean (EEIO) and the western Seychelles-Chagos thermocline ridge between 5 and $10^{\circ} \mathrm{S}$ (wSCTR). Changes in the shallow thermoclines seem to influence SST to a large extent in these areas (Fig. 3c). Three additional regions chosen for further investigation include areas of pronounced thermocline depth variability: the Southern Bay of Bengal (SBoB), Southern Tip of India (STI) and Western Arabian Sea (WAS).

The partial regression methods allow us to separate statistically the anomaly signals that are related "purely" to one climate mode (e.g. IOD), having removed the linear signal of the other climate mode (e.g. ENSO). Because many of the surface temperature and thermocline depth responses to these climate modes have been detailed in the literature, we do not treat them comprehensively here and mainly focus on features relevant to chlorophyll anomalies. The physical response to positive IOD events is characterised by clear zonal gradients of SST and thermocline depth anomalies in the equatorial region, which peak in boreal fall (Fig. 4; Saji et al., 1999; Webster et al., 1999). The observed changes in thermocline depth are fuelled by surface wind anomalies (Fig. 4, right column): During boreal fall, a strong easterly anomaly arises near the Equator, which triggers an equatorial Kelvin wave response and generates upwelling in the eastern equatorial region (Fig. 4b, d). The shoaling thermocline signal propagates as a coastal trapped Kelvin wave around the rim of the Bay of Bengal (in a counter-clockwise direction), as noted by Nidheesh et al. (2013) and Rao et al. (2010). An upwelling Rossby wave is reflected offshore (westwards) either side of the Equator, as illustrated by the two negative D20 lobes in Fig. 4b and d. Further west, the response is dominated by off-equatorial convergence due to Ekman pumping on the flanks of the equatorial easterly anomaly. The result is a deeper-than-normal D20 in the central and western Indian Ocean, which propagates westwards as symmetrical Rossby wave signals either side of the Equator, from fall until the following spring (Fig. 4d, f, h). These deepened thermocline anomalies have a larger amplitude and are more persistent in the Southern Hemisphere, where they interact with the normally shallow Seychelles-Chagos thermocline ridge (Hermes and Reason, 2008; Yokoi et al., 2008).

The similarities in spatial patterns of D20 and SST anomalies, together with the regional relationships highlighted in Fig. 3c, suggest that thermocline depth variability is respon-

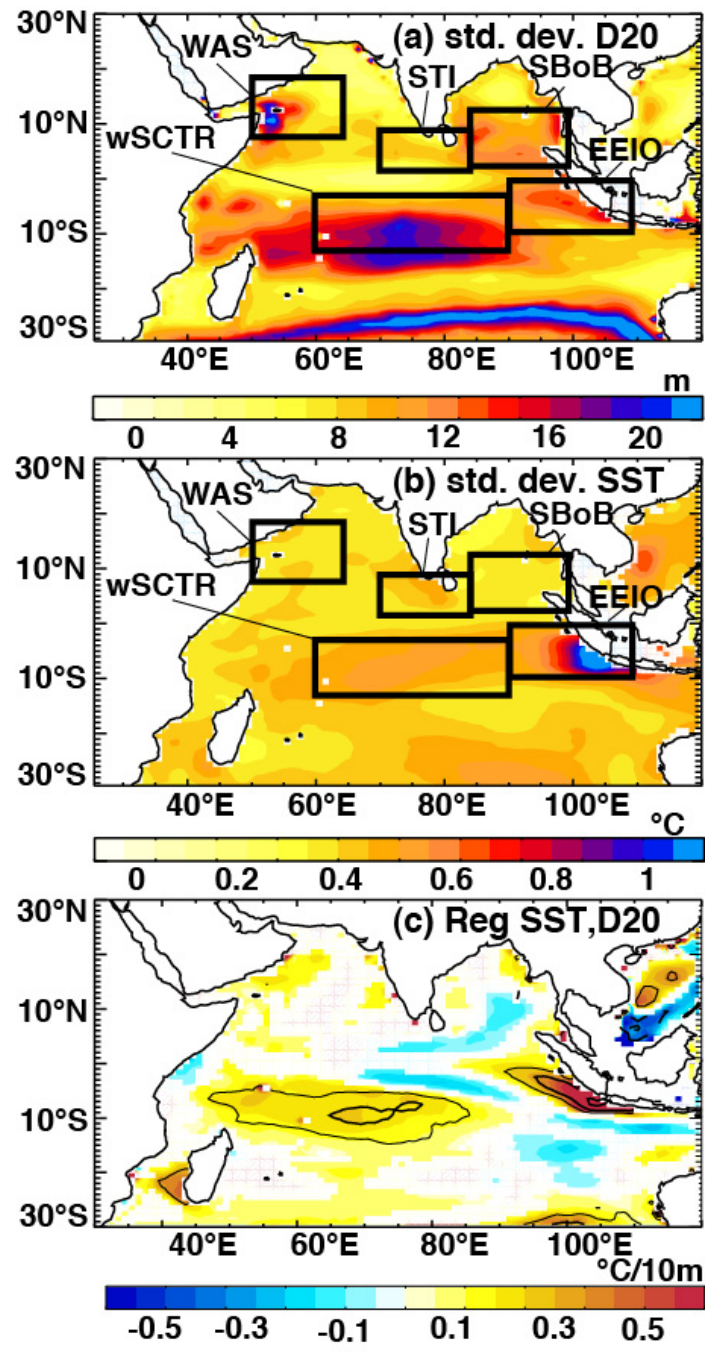

Fig. 3. Regional interannual variance of (a) D20 and (b) SST, as indicated by the standard deviation of their anomalies over the period 1961-2001. (c) Coefficients from a simple linear regression of SST and D20 anomalies over the same period, drawn only when beyond a $90 \%$ significance level. Thin and thick contours indicate correlation coefficients of 0.4 and 0.6 respectively, while solid (dashed) lines represent positive (negative) coefficients. Geographical boxes used in later analyses are shown in (a) and (b).

sible for a large proportion of IOD-linked surface temperature anomalies. However not all D20 anomalies are mirrored by SST responses. For example, D20 signals in the Bay of Bengal do not cause corresponding signals in overlying SST anomalies, likely due to the insulating effects of the nearsurface salinity-stratified barrier layer there (Howden and Murtugudde, 2001; Thadathil et al., 2007). Our results indicate a less-extensive and weaker ENSO influence on tropical thermocline variations than that of IOD. This finding is consistent with Rao et al. (2002), who suggest that interannual thermocline variability in the tropical Indian Ocean is governed mainly by the IOD. Contrasting Figs. 4 and 5 illustrates 


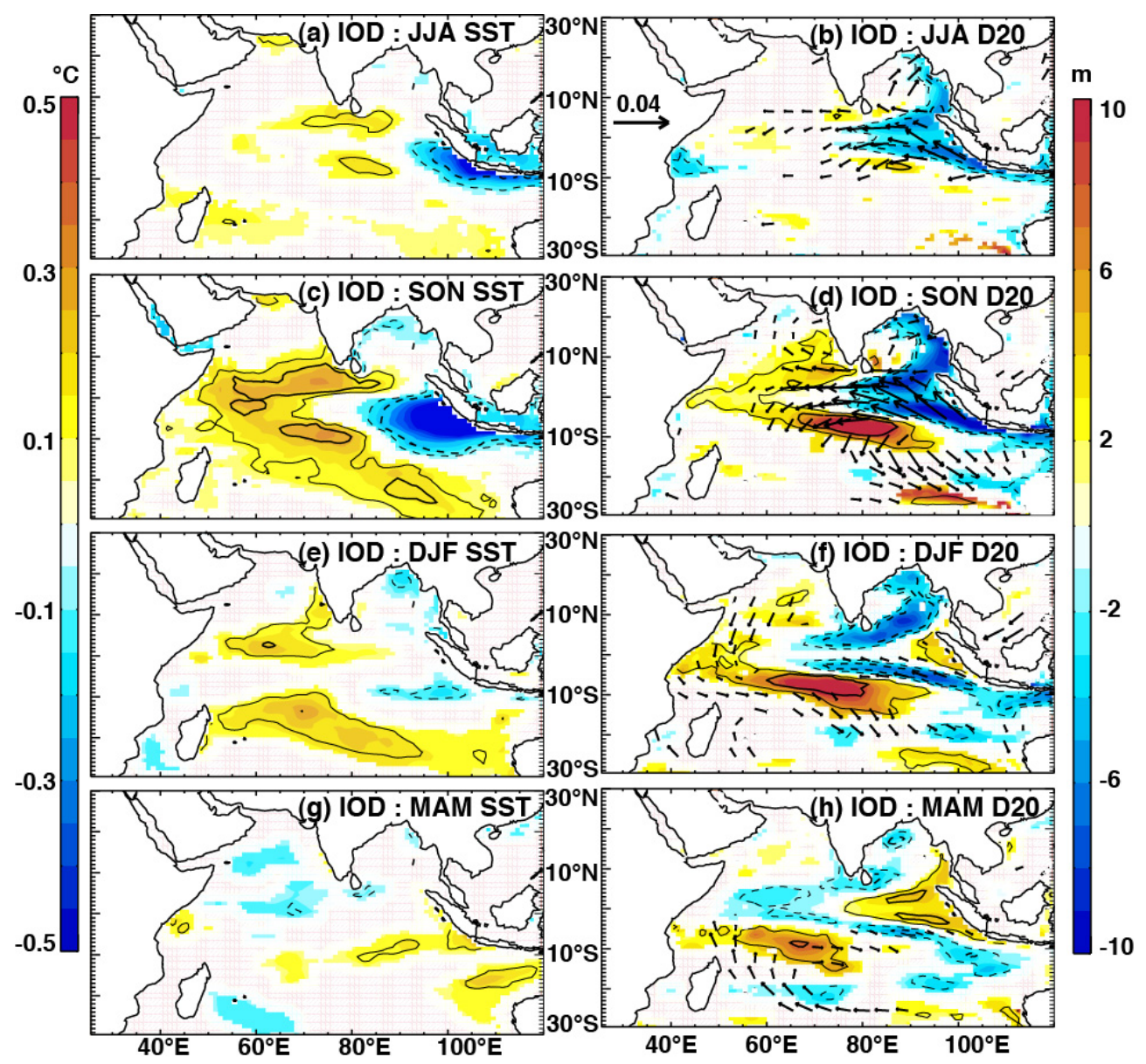

Fig. 4. The impacts of IOD on SST (left panels), D20 (colour; right panels) and wind stress (arrows; right panels), as indicated by partial regression coefficients of their anomalies regressed onto the IOD index, having removed the influence of ENSO (Eqs. 1-3). Regressions were computed for the period 1961-2001 and their coefficients were drawn only when beyond a 90\% significance level. Thin and thick contours indicate correlation coefficients of 0.4 and 0.6 respectively, while solid (dashed) lines represent positive (negative) correlations.

the distinct surface and subsurface impact of IOD and ENSO in the Indian Ocean (see also Rao and Behera, 2005; Yu et al., 2005). Whereas the IOD-related SST signal dissipates during winter, the basin-wide ENSO signal establishes during winter and peaks in spring (Klein et al., 1999; Xie et al., 2009), about 4-6 months after the mature phase of the IOD. Similar to IOD, ENSO-related anomalous equatorial easterly winds cause shallow D20 anomalies off Sumatra and in the eastern Bay of Bengal, while concurrent deepening of the thermocline develops in the southern Indian Ocean in response to Ekman pumping (Fig. 5f). These ENSO anomalies are, however, delayed by at least a season compared to those of IOD and are less intense. The deep anomalies in the southern Indian Ocean propagate westwards during spring (Fig. 5h), consistent with a Rossby wave signal, but are weaker and centred further south than the corresponding IOD anomalies, congruent with the findings of Rao and Behera (2005) and Yu et al. (2005).
Even though ENSO does raise the thermocline near the eastern boundary in winter (Fig. 5f), strong upwellingfavourable winds that might lift these cooler waters to the surface (and thereby transfer the signal to SST) are likely stunted or precluded at this time of year by the monsoonrelated wind reversal in the Northern Hemisphere (Schott et al., 2009; Xie et al., 2002).

\subsection{Biological response}

Certain regions in the Indian Ocean are characterised by pronounced variability of interannual chlorophyll anomalies (Fig. 6a, b). Within the Arabian Sea, there is enhanced variability of both surface and integrated chlorophyll associated with two known upwelling regions: the Somalia upwelling (within the WAS box) and near the Southern tip of India (STI box). Areas of marked variability of both surface and integrated chlorophyll are also evident in the SBoB and the 


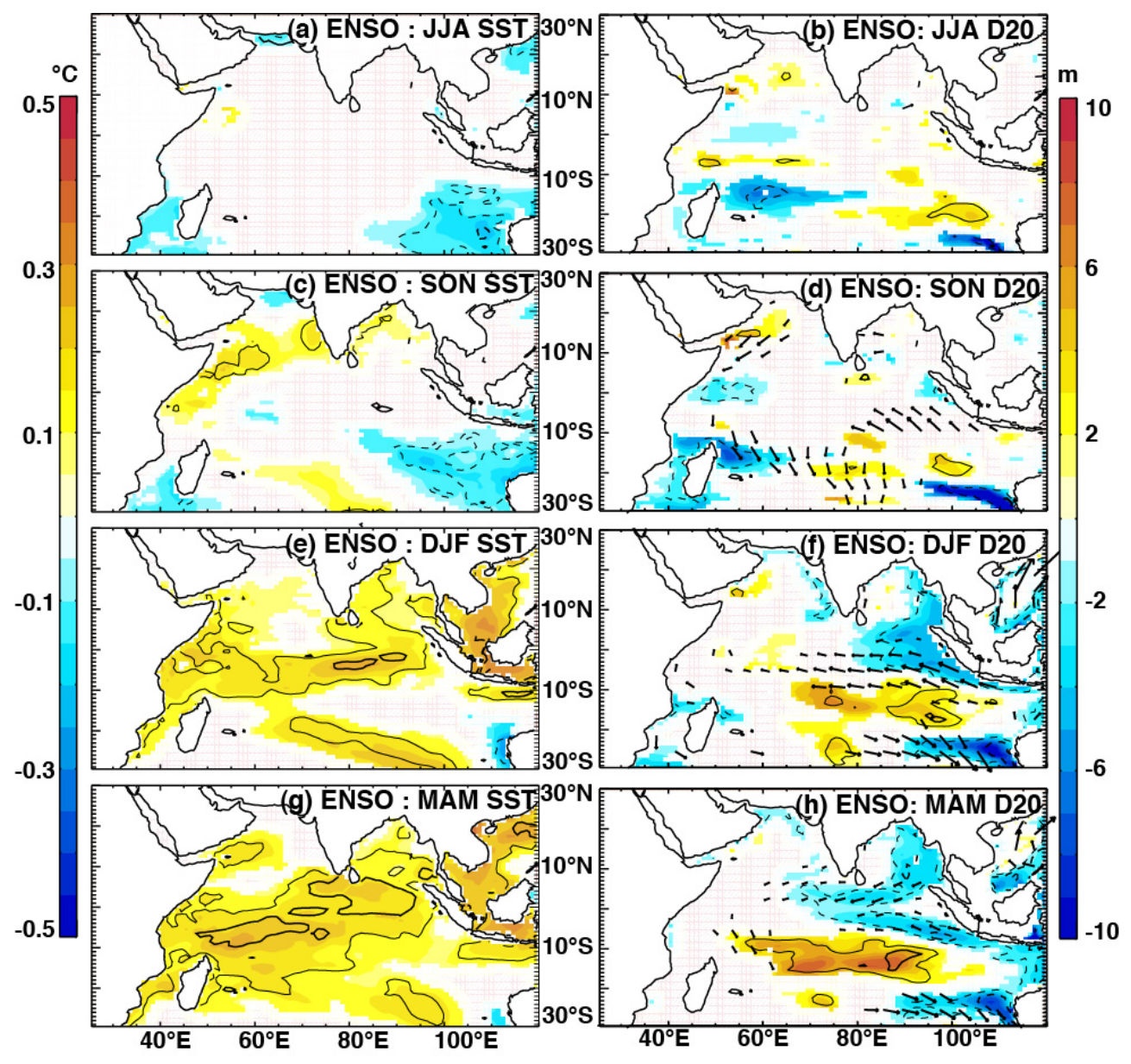

Fig. 5. The impacts of ENSO on SST (left panels), D20 (colour; right panels) and wind stress (arrows; right panels), as indicated by partial regression coefficients of their anomalies regressed onto the ENSO index, having removed the influence of IOD (Eqs. 4-6). Regressions were computed for the period 1961-2001 and their coefficients were drawn only when beyond a $90 \%$ significance level. Thin and thick contours indicate correlation coefficients of 0.4 and 0.6 respectively, while solid (dashed) lines represent positive (negative) correlations.

EEIO. The wSCTR area shows marked variability in $I$ Chl (Fig. 6a), yet no corresponding signal in $S \mathrm{Chl}$ (Fig. 6b).

Regression of $I \mathrm{Chl}$ on D20 reveals a significant negative relationship throughout most of the tropical Indian Ocean (Fig. 6c). Changes in thermocline depth control the proximity of fertile subsurface waters to the sunlit euphotic zone and thereby affect phytoplankton productivity (Lewis et al., 1986; Messié and Chavez, 2012). The downwelling and resultant deep nutricline (thermocline) characteristic of ocean gyres means that horizontal advection of nutrients from adjacent regions can play a greater role in chlorophyll responses there than vertical changes in the thermocline depth (McClain et al., 2004). This may explain the non-significant coefficients in the gyre regions west of Australia. Similarly, the central Arabian Sea is dominated by Ekman convergence in boreal summer (Schott et al., 2009), which together with strong coastal upwelling and offshore advection of nutrientrich waters from the Somali and Oman coasts, might explain the lack of a significant relationship in the western half of the Arabian Sea.

$S \mathrm{Chl}$ anomalies are negatively related to D20 mainly in upwelling regions (Java/Sumatra coast; western coast and southern tip of India; to a lesser degree Somalia and Oman upwelling; Fig. 6d), where shallower thermoclines (nutriclines) would result in entrainment of increased nutrients into surface waters during upwelling. There is no seasonal upwelling in the central and northern regions of the Arabian Sea and Bay of Bengal; the negative relationship in these areas might be a result of heightened nutrient entrainment by winter mixing events that occur during periods of shallower thermoclines. Wiggert et al. (2002) argue that mixed-layer nutrients are not limiting in the central Arabian Sea and suggest that such a negative relationship might be caused by the thermocline depth regulating a large-amplitude diurnal cycle, the latter of which can cause a greater loss of phytoplankton biomass from the euphotic zone during periods of deep thermoclines than during periods of shallower thermoclines. 


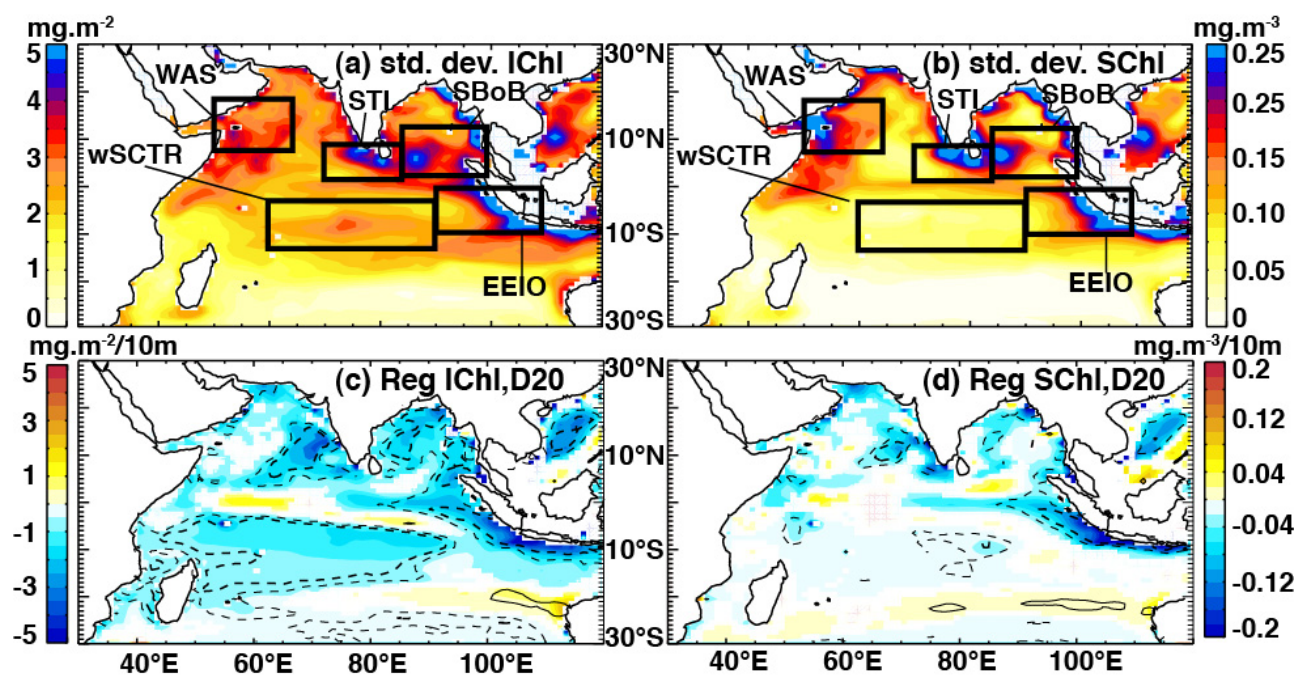

Fig. 6. Regional interannual variance of (a) $I \mathrm{Chl}$ and (b) $S \mathrm{Chl}$, as indicated by the standard deviation of their anomalies over the period 19612001. (c) Coefficients from a simple linear regression of $I \mathrm{Chl}$ and (d) $S \mathrm{Chl}$ anomalies regressed onto D20 anomalies over the same period. Regression coefficients were drawn only when beyond a $90 \%$ significance level. Thin and thick contours indicate correlation coefficients of 0.4 and 0.6 respectively, while solid (dashed) lines represent positive (negative) coefficients. Geographical boxes used in later analyses and selected on the basis of regional biogeochemical variability are shown in (a) and (b).

However, the simulation used here was forced with daily fields, therefore a diurnal effect would not explain the relationship between $S \mathrm{Chl}$ and D20 anomalies in our case. Beyond those discussed above, most open-ocean regions reveal a weak or insignificant relationship between SChl and D20, indicative that factors beyond the vertical nutricline proximity play a greater role in controlling surface chlorophyll anomalies in these areas. The regions that display a significant $I$ Chl-D20 relationship, but not a $S$ Chl-D20 relationship, are areas where changes in a relatively deep thermocline and a deep chlorophyll maximum may have minimal bearing on the overlying $S \mathrm{Chl}$.

As expected from the widespread relationship seen in Fig. 6c, IOD-related anomalies of IChl show similar (but opposite) patterns to those of D20 (left panels in Fig. 7 and right panels in Fig. 4 respectively). IOD exerts a striking control on $I \mathrm{Chl}$, predominantly via its substantial influence on regional thermocline depths. The eastern shoaling of D20 results in enhanced IChl along the Java and Sumatra coast and in the southeastern BoB, starting in summer (Fig. 7a) and spreading and intensifying in fall (Fig. 7c). While these anomalies largely dissipate in winter along the Java/Sumatra coast, they persist in the SBoB (Fig. 7e). Positive $I \mathrm{Chl}$ anomalies in the eastern and northern BoB likely follow from the coastal trapped Kelvin wave that shoals the thermocline around the perimeter of the Bay (Fig. 4b, d, f; Rao et al., 2002). A horseshoe-shaped pattern of negative chlorophyll anomalies develops in the central and western basin in fall, with strongest expression either side of the Equator and greatest persistence in the shallow thermocline ridge region (Fig. 7c, e), similar to the patterns of IODrelated D20 anomalies (Fig. 4d).

The $S C h l$ signals show spatial patterns that are in many ways similar to those of IChl (Fig. 7a-d): Strong IODrelated positive anomalies develop along the Java and Sumatra coast, starting in boreal summer and peaking in fall, before dissipating in winter. The bloom in the southeastern $\mathrm{BoB}$ starts in fall and persists throughout the winter season. The southwestern coast and southern tip of India display a strong chlorophyll decrease in summer and fall. A notable difference between the $S \mathrm{Chl}$ and $I \mathrm{Chl}$ anomalies is that the negative western surface anomalies are less extensive and disappear for the most part in winter (Fig. 7f), in contrast to those of $I \mathrm{Chl}$, which remain prominent and propagate westwards during this season (Fig. 7e). This difference is related to the lack of relationship between D20 and SChl (Fig. 6d) as opposed to IChl (Fig. 6c) in this region. The depressed D20 and subsurface chlorophyll anomalies do not seem to reach surface chlorophyll in these areas in boreal winter.

As with D20, the biological response to ENSO is generally weaker and occurs later (Fig. 8) compared to that of the IOD (Fig. 7). Positive $I \mathrm{Chl}$ anomalies develop along the eastern boundary in boreal winter and spring (Fig. 8e, g). Concurrently, lower-than-normal $I \mathrm{Chl}$ concentrations develop in the wSCTR region between $\sim 8$ and $15^{\circ} \mathrm{S}$, and also to a lesser degree on the northern side of the Equator, with very little expression in $S \mathrm{Chl}$ (Fig. 8f, h). The largest ENSO-related $S C h l$ signal seems to be in fall and winter in the western Arabian Sea, offshore of the Oman and Somalia upwelling region (Fig. 8d, f). A similar, but less extensive signal is seen in $I \mathrm{Chl}$ anomalies in the same region (Fig. 8c, e, g). ENSO is 


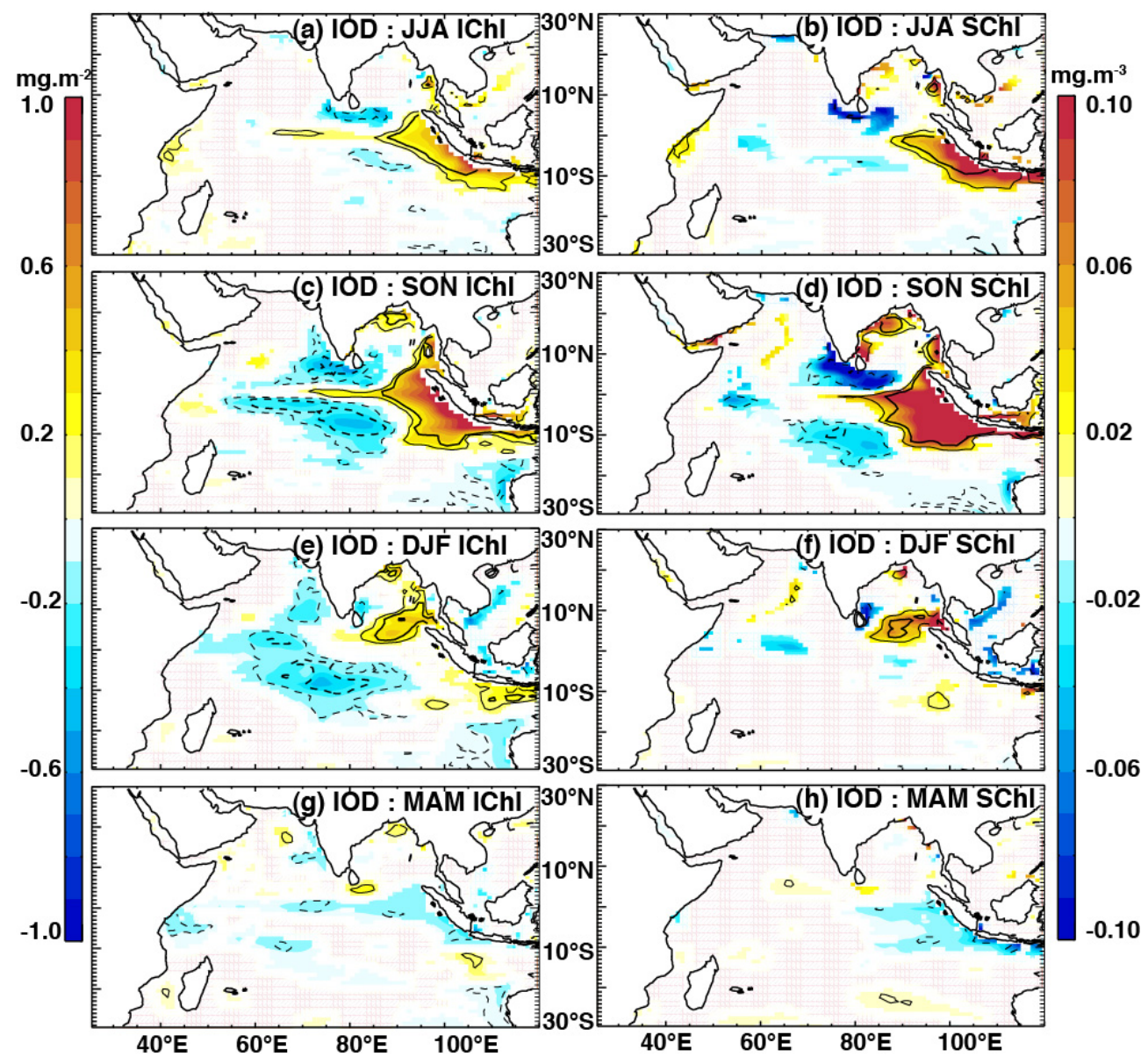

Fig. 7. The impacts of IOD on IChl (left panels) and SChl (right panels), as indicated by partial regression coefficients of their anomalies regressed onto the IOD index, having removed the influence of ENSO (Eqs. 1-3). Regressions were computed for the period 1961-2001 and their coefficients were drawn only when beyond a $90 \%$ significance level. Thin and thick contours indicate correlation coefficients of 0.4 and 0.6 respectively, while solid (dashed) lines represent positive (negative) correlations.

associated with northeasterly wind anomalies in the western Arabian Sea in boreal fall (Fig. 5d). The Oman and Somalia upwelling systems are likely sensitive to changes in surface winds and these ENSO-related northeasterly anomalies act to reduce upwelling, causing deeper-than-normal thermoclines and warmer-than-normal SSTs (Fig. 5c, d), as well as the chlorophyll impacts noted above.

\subsection{Anomalies in key regions}

Contrasting Figs. 4 and 5, and 7 and 8, it is clear that the responses to ENSO and IOD forcing differ in space and time. These contrasting impacts, and their seasonality, were more closely examined within specific regions (Fig. 9). There is considerable variability amongst the relative strength and/or state of both climate modes across different years. Plots of the average $I \mathrm{Chl}$ anomalies versus climate indices during all years (Fig. 10) illustrate this variability and helps visualise the correlative strength between climate mode and chlorophyll anomalies across different regions. Unexpectedly, Fig. 10 also revealed an apparent asymmetry in the consequences of the climate modes on chlorophyll concentrations in some areas.

In the EEIO region, the IOD causes a shoaling of the thermocline, and soon thereafter cool SSTs from June/July to December/January (Fig. 9a). The shallow thermocline promotes entrainment of nutrients and results in anomalously high surface and integrated chlorophyll concentrations from $\sim$ June/July to December (Fig. 9b). Murtugudde et al. (1999) and Wiggert et al. (2009) have previously documented these blooms during simultaneous positive IOD/El Niño events. Our analyses attribute those positive anomalies to a dominantly IOD control, with ENSO seemingly exerting a significant influence on the thermocline only from November onwards (Fig. 9a) and causing relatively modest increases of $I \mathrm{Chl}$ after January (Fig. 9b). Figure 10a shows that the largest positive $I \mathrm{Chl}$ anomalies in SON correspond to pure IODs, or co-occurring ENSO and IODs, but not pure ENSO 


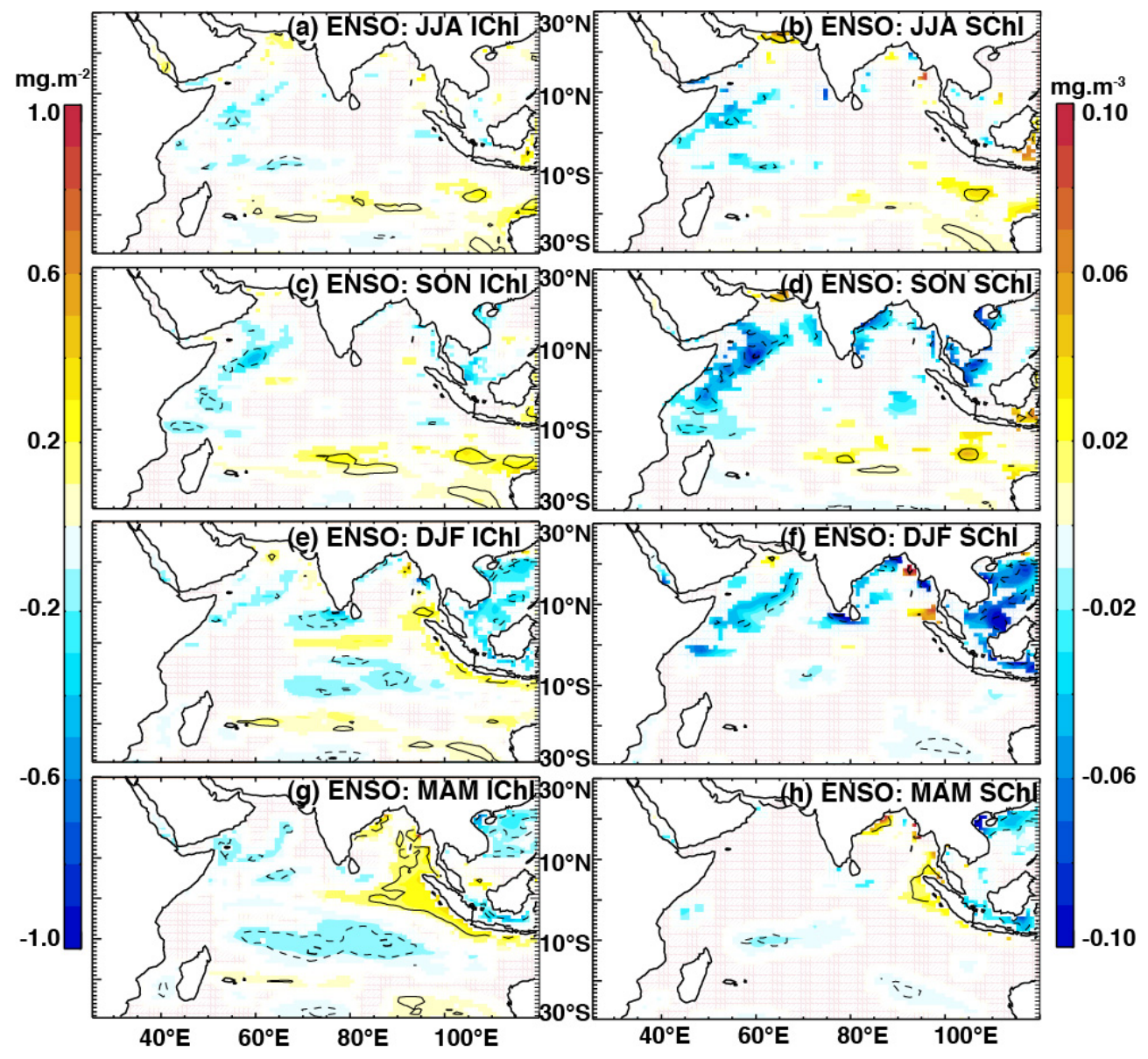

Fig. 8. The impacts of ENSO on IChl (left panels) and SChl (right panels), as indicated by partial regression coefficients of their anomalies regressed onto the ENSO index, having removed the influence of IOD (Eqs. 4-6). Regressions were computed for the period 1961-2001 and their coefficients were drawn only when beyond a $90 \%$ significance level. Thin and thick contours indicate correlation coefficients of 0.4 and 0.6 respectively, while solid (dashed) lines represent positive (negative) correlations.

events. This, together with the statistics in Tables 1 and 2 and the patterns of partial regression coefficients in Figs. 7, 8 and 9 support our conclusion that anomalous phytoplankton blooms in the EEIO region are predominantly due to IOD forcing. Figure 10a also suggests that positive $I \mathrm{Chl}$ anomalies in the EEIO region generally tend to be of greater magnitude than negative ones.

In the wSCTR region, deeper thermoclines coincide with warmer surface temperatures in response to ENSO and IOD (Fig. 9c), consistent with results of previous studies (Meyers et al., 2007; Rao and Behera, 2005; Xie et al., 2002). The IOD produces slightly earlier thermocline anomalies than ENSO and the ENSO-related surface warming initiates and peaks later than that of IOD. ENSO-related chlorophyll anomalies (both at the surface and over the euphotic layer) seem relatively weak and start to be significant only in boreal winter in this region (Fig. 9d). The clearest biogeochemical signature is seen in response to IOD, with depleted SChl during the IOD peak ( August to November) and negative $I \mathrm{Chl}$ coinciding with the deeper-than-normal D20 signal ( August to April). Although both IOD and ENSO are related to significant negative anomalies during DJF (Table 2), the percentage of chlorophyll variability explained by the IOD is far greater than that of ENSO (Table 3). There is no clear asymmetry between positive and negative chlorophyll anomalies in the wSCTR region (Fig. 10b). The largest (negative) anomalies are associated with pure IOD or co-occurring ENSO and IOD events.

In contrast to the two regions discussed above, the SBoB surface temperature and thermocline depth anomalies seem less coupled (Fig. 9e), likely due to a stratified barrier layer isolating the surface temperatures from subsurface influence (Howden and Murtugudde, 2001; Sprintall and Tomczak, 1992; Thadathil et al., 2007; Wiggert et al., 2009). ENSO and IOD both result in shallower-than-normal D20, but only ENSO results in a significant SST change, causing warmer anomalies that start in late fall (Fig. 9e). Similar to other regions, a temporal lag is obvious between IOD and ENSO 

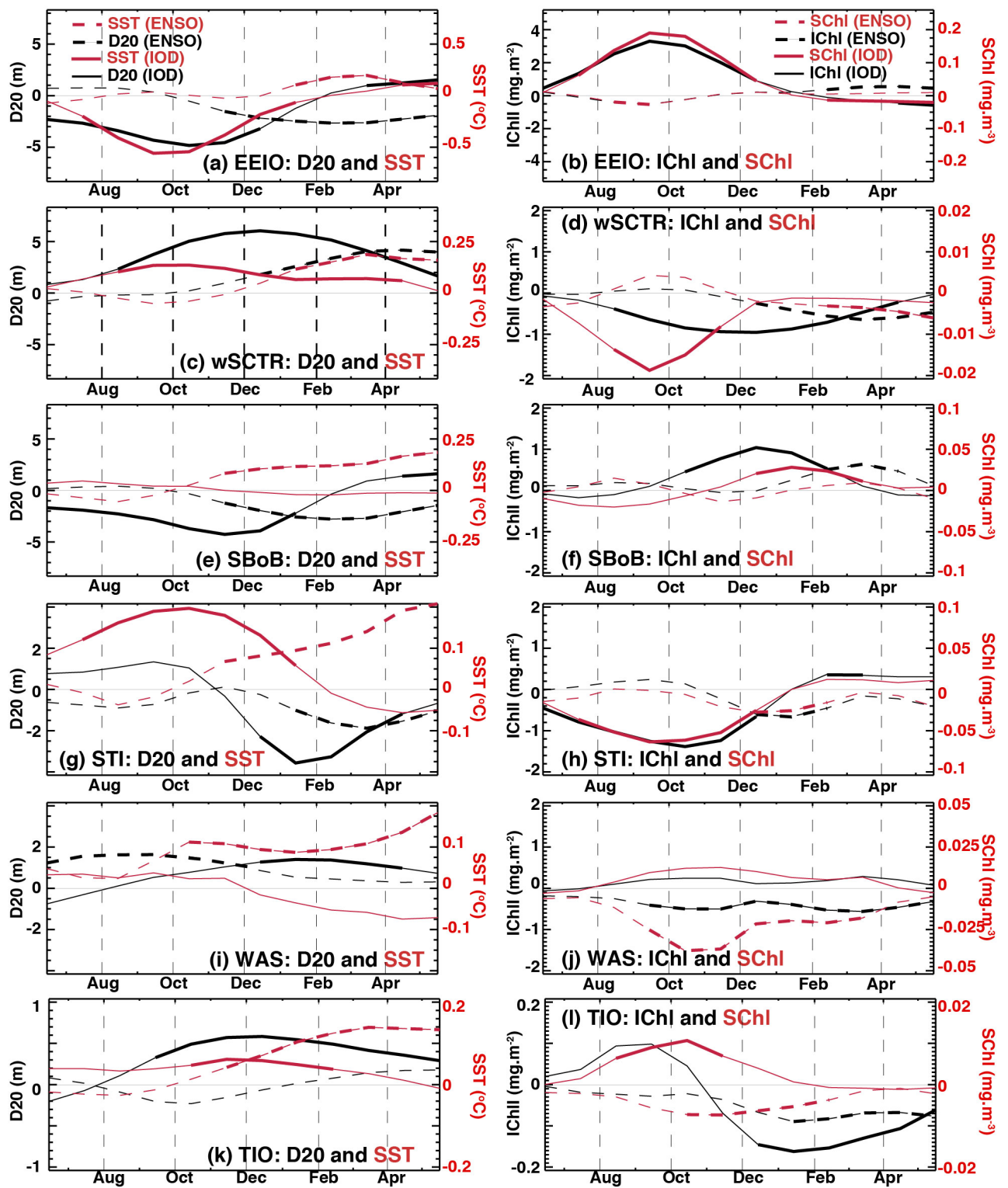

Fig. 9. Seasonal evolution of the IOD (solid) and ENSO (dashed) impacts on D20 (black) and SST (red) anomalies in the left column, and $I \mathrm{Chl}$ (black) and SChl (red) anomalies in the right column, as indicated by partial regression coefficients of these anomalies regressed onto the respective climate index, having removed the influence of the second/remaining climate index (Eqs. 1-3 for solid lines; Eqs. 4-6 for dashed lines). The geographical regions are indicated on Figs. 3 and 6 and described in Sect. 2.3. Bold line segments indicate when partial regression coefficients are beyond the $90 \%$ significance level.

effects. The prominent shoaling of the thermocline in the central SBoB, a result of an upwelling Rossby wave following a positive IOD event (Fig. 4f; Wiggert et al., 2009), results in an increase in $I \mathrm{Chl}$ from $\sim$ October to February. An increase in $S \mathrm{Chl}$ in response to the shallower nutricline (shoaling thermocline) occurs only during winter (Fig. 9f), likely because winter cooling and stronger winds allow windmixing of the surface layers that are otherwise highly stratified during the remainder of the year (Prasanna Kumar et al., 2010). Positive $I \mathrm{Chl}$ anomalies are seen in response to ENSO from mid February to early April, although without a significant $S$ Chl signal (Fig. 9f), as greater nutrients are brought toward the euphotic zone by a shoaling thermocline, but do not reach surface layers. Although both IOD and ENSO produce significant chlorophyll anomalies (Table 2), IOD variability seems to dominate and explains a far greater proportion of both $S \mathrm{Chl}$ and $I \mathrm{Chl}$ anomalies (Table 3). Positive chlorophyll anomalies are generally larger than negative ones in the $\mathrm{SBoB}$ region (Fig. 10c) and are never the result of pure ENSO events (but either IOD or IOD + ENSO). 
Table 2. Partial regression coefficients (and partial correlation coefficients in brackets) of $I \mathrm{Chl}\left(\mathrm{mg} \mathrm{m}^{-2}\right) \mathrm{and}^{S C h l}\left(\mathrm{mg} \mathrm{m}{ }^{-3}\right)$ anomalies versus the relevant climate index (DMI and Niño3.4). The season selected is that in which the multiple regression including DMI + Niño3.4 explained the greatest proportion of $I \mathrm{Chl}$ or $S \mathrm{Chl}$ variance (which is quoted in Table 3). Bold figures denote significant regression or correlation coefficients $(p<0.05)$.

\begin{tabular}{|c|c|c|c|c|c|c|}
\hline \multirow[t]{2}{*}{ Region } & \multicolumn{3}{|c|}{ IChl } & \multicolumn{3}{|c|}{ SChl } \\
\hline & Season & IOD & ENSO & Season & IOD & ENSO \\
\hline EEIO & SON & $3.015(0.92)$ & $-0.237(-0.18)$ & SON & $0.180(0.94)$ & $-0.012(-0.19)$ \\
\hline wSCTR & DJF & $-0.873(-0.74)$ & $-0.411(-0.46)$ & SON & $-0.015(-0.50)$ & $0.003(0.14)$ \\
\hline SBoB & DJF & $1.272(0.67)$ & $0.510(0.29)$ & DJF & $0.044(0.57)$ & $0.013(0.20)$ \\
\hline STI & SON & $-1.404(-0.72)$ & $0.113(0.08)$ & SON & $-0.062(-0.62)$ & $-0.006(-0.07)$ \\
\hline WAS & MAM & $0.207(0.18)$ & $-0.461(-0.38)$ & DJF & $0.007(0.12)$ & $-0.020(-0.34)$ \\
\hline TIO & DJF & $-0.162(-0.54)$ & $-0.090(-0.34)$ & SON & $0.011(0.44)$ & $-0.007(-0.32)$ \\
\hline
\end{tabular}

Table 3. Percentage of interannual chlorophyll variance explained by regressions including DMI + Niño3.4 as explanatory variables (first column) and for the partial regression of each climate mode in isolation (2nd and 3rd columns; proportion from Eq. 7 multiplied by 100). The season selected was that in which the multiple regression (first column) explained the greatest proportion of $I$ Chl or $S C h l$ variance. Bold figures indicate when partial regressions resulted in a significant coefficient $(p<0.05)$.

\begin{tabular}{|c|c|c|c|c|c|c|c|c|}
\hline \multirow[b]{2}{*}{ Region } & \multicolumn{4}{|c|}{$I \mathrm{Chl}$} & \multicolumn{4}{|c|}{$S \mathrm{Chl}$} \\
\hline & Season & $\begin{array}{l}\text { IOD + } \\
\text { ENSO }\end{array}$ & IOD & ENSO & Season & $\begin{array}{l}\text { IOD + } \\
\text { ENSO }\end{array}$ & IOD & ENSO \\
\hline EEIO & SON & 89 & 62 & 0 & SON & 92 & 64 & 0 \\
\hline wSCTR & DJF & 77 & 27 & 6 & SON & 28 & 24 & 2 \\
\hline SBoB & DJF & 68 & 26 & 4 & DJF & 52 & 23 & 2 \\
\hline STI & SON & 60 & 42 & 0 & SON & 53 & 30 & 0 \\
\hline WAS & MAM & 15 & 3 & 15 & DJF & 12 & 4 & 11 \\
\hline TIO & DJF & 56 & 18 & 6 & SON & 20 & 20 & 9 \\
\hline
\end{tabular}

In the STI region, a significant shoaling of D20 develops between $\sim$ December and April in response to IOD, preceded by warmer-than-normal SSTs between $\sim$ July and January (Fig. 9g). ENSO events also show warming of surface waters, starting $\sim$ November and growing in magnitude until May. During much of the same time ( $\sim$ January to May), these warm SST anomalies are accompanied by a shoaling thermocline. The main biogeochemical signal is a decrease of both surface and integrated chlorophyll during IOD events ( $\sim$ June/July to December), while ENSO causes a brief period of negative anomalies during winter. During the SON peak expression of climate-mode-related anomalies, the IOD signal completely dominates ENSO in terms of explanatory power of the chlorophyll variability (Table 3). The lack of obvious coupling between thermocline depths and surface temperature or chlorophyll in this region is likely due to intense horizontal circulation between the Bay of Bengal and the Arabian Sea (e.g. Vinayachandran et al., 1999), as well as the added complexity of seasonal barrier layers in these regions (Sprintall and Tomczak, 1992). One needs to bear in mind also that mesoscale eddies have been invoked as being important for ecosystem variability in the BoB (Prasanna Kumar et al., 2007), but were not resolved here.
In contrast to all other examined regions, where IOD explains a greater proportion of chlorophyll variability, biological activity in the western Arabian Sea is influenced predominantly by ENSO (Tables 1, 2), causing depressed $S \mathrm{Chl}$ and $I \mathrm{Chl}$ anomalies from $\sim$ September to the following spring (Fig. 9j). These negative anomalies follow an anomalously deep thermocline between May and November and coincide with warmer-than-normal SST from October onwards (Fig. 9i). The ENSO-linked low-chlorophyll content in this upwelling region may be linked to an anomalously weak monsoon jet in fall (Fig. 5d) and/or early withdrawal of the summer monsoon during ENSO events (Syroka and Toumi, 2004; Xavier et al., 2007). Either way, it is interesting to note that the northeasterly anomalies in SON (Fig. 5d) seem to be preceded by deeper-than-normal D20 starting as early as June. The deeper thermocline likely contributes to lower nutrient concentrations and warmer surface temperatures during upwelling periods, by isolating the cooler, nutrient-rich, sub-thermocline waters further from the surface. Although these anomalies are significantly related to ENSO, a relatively low proportion (11-15\%) of the interannual chlorophyll variability is explained by the Niño3.4 index (Table 3). Other factors, such as ecosystem dynamics or 
(a)

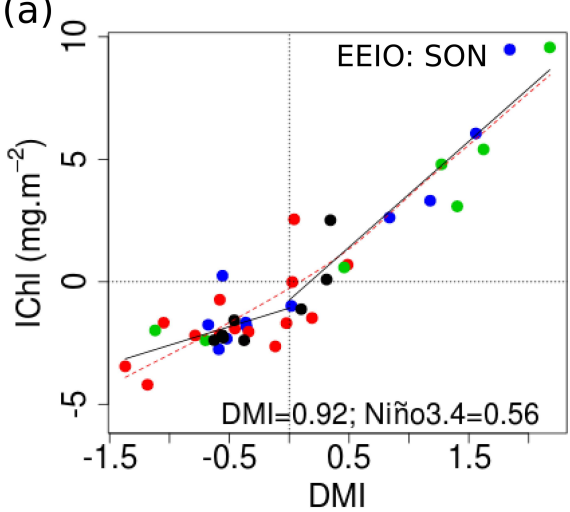

(c)

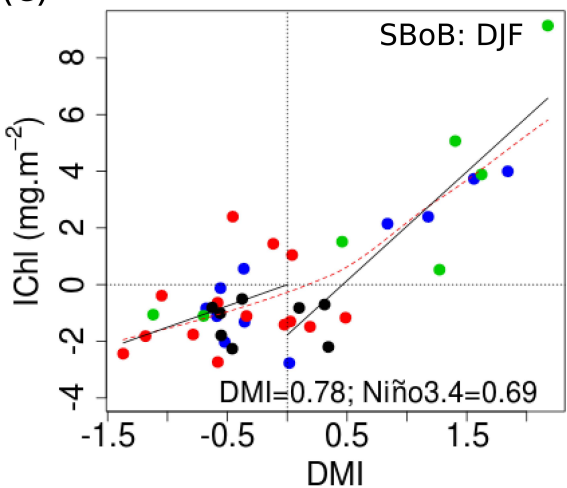

(e)

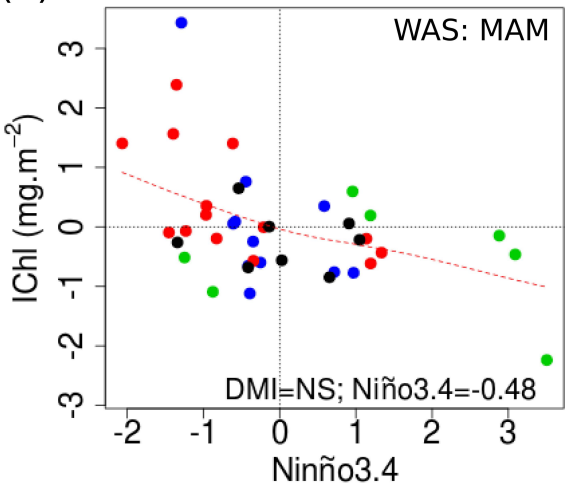

(b)

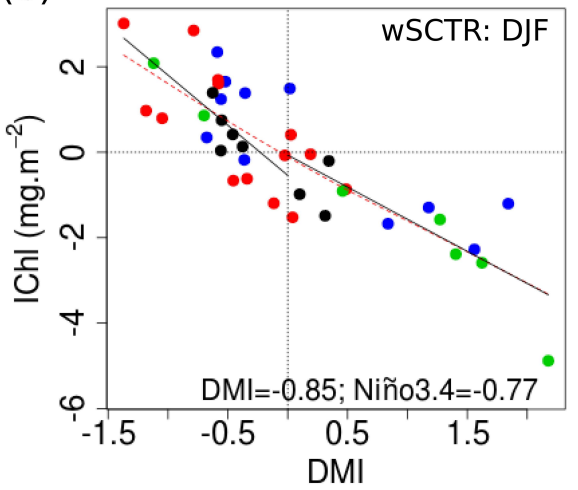

(d)

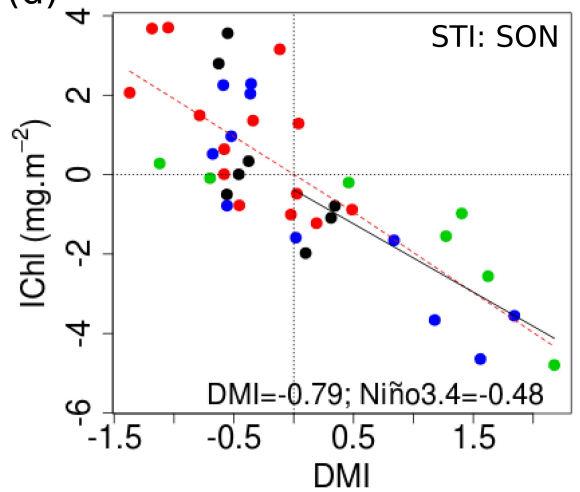

(f)

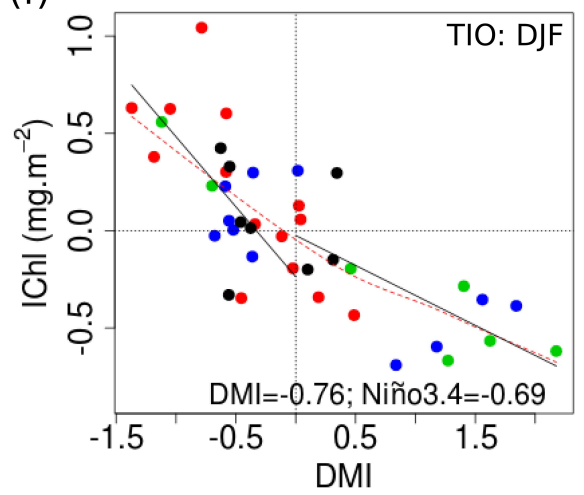

Fig. 10. Scatterplots showing the magnitude of $I \mathrm{Chl}$ anomalies against climate mode indices across all years (1961-2001). IChl anomalies are averaged over the regions of interest and over the same seasons as selected in Tables 1 and 2, namely: (a) EEIO in SON, (b) wSCTR in DJF, (c) SBoB in DJF, (d) STI in SON, (e) WAS in MAM and (f) TIO in DJF. Climate mode events as identified by Meyers et al. (2007) are indicated by colour: pure IOD events are blue, pure ENSO events red, co-occurring events green and non-event years black. Significant correlation coefficients $(p<0.05)$ between $I \mathrm{Chl}$ and climate indices are provided on the plot or indicated as NS (not significant; $p \geq 0.05$ ). Solid black lines represent the slopes of significant regressions $(p<0.05)$, fit separately to index values $>0$ and $<0$. Dashed red lines illustrate loess smooth curves fit by least squares (allowing a non-linear best fit).

monsoon-related forcing may instead play significant roles in affecting interannual anomalies in this region. The IOD seems to have relatively little impact in this region, causing a deeper-than-normal thermocline between $\sim$ December and April, but neither SST nor chlorophyll anomalies. Figure 9j and Tables 1 and 2 point to ENSO but not IOD controlling chlorophyll anomalies in the WAS region.
The integrated influences of IOD and ENSO over the entire tropical Indian Ocean basin (TIO) are shown in Fig. 9k and 1 . At this scale, the IOD has a significant positive effect on D20 from $\sim$ September to May, while ENSO seems to display no overall influence on D20 (Fig. 9k). Both climate modes produce warmer-than-average SSTs, with a delayed, longer-lasting and more intense signal for ENSO 
( $\sim$ November to May) than for IOD ( $\sim$ October to February; Schott et al., 2009; Xie et al., 2009). Despite the deeperthan-normal D20 associated with IOD, SChl anomalies show a brief positive period during the IOD peak ( $\sim$ August to November), which suggests that the chlorophyll bloom in the eastern pole dominates the basin-wide response during those months. On the other hand, basin-wide IChl becomes significantly less-than-normal in winter and spring in response to IOD (Fig. 91), driven largely by the horseshoe-shaped negative anomalies in the western basin and thermocline ridge region (Fig. 7e). ENSO-related chlorophyll signals are negative for both surface ( $\sim$ October to February) and depthintegrated values ( $\sim$ January to May), suggestive of an overall negative effect on basin-scale chlorophyll concentration. The positive influence of IOD and negative effect of ENSO on SChl likely counter-act one another during years when these events co-occur, such as in 1997 and 2006. Their combined effect, however, explains only about $20 \%$ of interannual $S$ Chl variability (Table 3 ), which may be additionally affected by further climate or ecosystem dynamics.

\section{Summary and discussion}

The remotely-sensed chlorophyll record is too short to confidently differentiate the relative contributions of IOD and ENSO to interannual variability. A novel contribution of our study is to effectively separate ENSO and IOD impacts within the Indian Ocean and to investigate these in six regions, using a $41 \mathrm{yr}$ hindcast from a coupled biophysical general circulation model. Although focus was on the response of chlorophyll, changes in thermocline depth, surface temperature and surface winds were also assessed in order to gain a better understanding of physical processes driving the biological patterns. In comparison with SeaWiFS data, the modelled $S \mathrm{Chl}$ showed good qualitative agreement of open-ocean seasonal variability and interannual anomalies during the 1997/1998 El Niño/positive IOD event. This, despite lacking some of the spatial contrasts or complexity seen in SeaWiFS (especially in coastal regions), which are likely structured by meso- and smaller-scale processes not resolved by the simulation. As a result, interpretations were intentionally limited to broad regional patterns.

Although previous studies have not isolated IOD and ENSO signals in chlorophyll anomalies, the patterns described from co-occurring IOD/ENSO events (Murtugudde et al., 1999; Sarma, 2006; Vinayachandran and Mathew, 2003; Wiggert et al., 2009) are consistent with results presented here. Wiggert et al. (2009) use SeaWiFS chlorophyll records to assess the Indian Ocean response to the two positive IOD/El Niño events of 1997 and 2006, and interpret these in light of physical forcing and their resultant impacts on primary productivity. In agreement with our results, they find surface chlorophyll and net primary production increases in the eastern tropical Indian Ocean in boreal fall and in the southeastern Bay of Bengal in winter, as well as negative primary production anomalies in the southwestern Indian Ocean in fall and winter. Wiggert et al. (2009) note a negative chlorophyll anomaly around the southern tip of India between October and December in both their events. The substantial IOD-forced decrease in IChl (and by deduction primary productivity) in this region has not been established elsewhere to the best of our knowledge.

The IOD produces anomalous dynamic (thermocline depth and Rossby-Kelvin wave) and thermodynamic (mixed layer, SST, and heat flux) variability, with phytoplankton communities responding to the sum total of these dynamicalthermodynamical influences on the upper ocean. Across most of the Indian Ocean, $I \mathrm{Chl}$ changes are strongly related to anomalies of D20 (Fig. 6c), explained by the importance for phytoplankton productivity of the vertical proximity of high-nutrient subsurface waters to the sunlit euphotic layer (Lewis et al., 1986; Messié and Chavez, 2012; Wilson and Adamec, 2002). Messié and Chavez (2012) recently highlighted the dominant role of nutricline depths in controlling changes in chlorophyll and productivity at the global scale. As ENSO and IOD are not orthogonal, their analyses would not effectively separate the signatures of these two modes, and their ENSO-correlated EOFs of chlorophyll and productivity likely contain a proportion of IOD-related expression in the Indian Ocean.

There are, of course, regions in the Indian Ocean where neither IOD nor ENSO seem to control chlorophyll anomalies. Other drivers not investigated here, such as the Indian monsoon, intra-annual climate perturbations and ecosystem dynamics might affect interannual chlorophyll anomalies in these regions. The ecosystem could influence chlorophyll concentration via top-down grazing control, as well as bottom-up nutrient regeneration and fertilisation of surface waters by zooplankton and higher trophic levels. A dominance of regenerated production in stratified, nutrientstarved, low-chlorophyll areas is an explanation suggested for the apparent asymmetry in chlorophyll anomalies seen between positive and negative climate events in some regions (Fig. 10). Such an explanation, if correct, would be an example of ecosystem dynamics mitigating the magnitude of climate-induced negative chlorophyll anomalies.

Our results suggest that ENSO has a weaker and lagged effect on thermocline and chlorophyll anomalies in comparison to IOD. The only region where chlorophyll signals are predominantly related to ENSO (and not IOD) variability is the western Arabian Sea in (and offshore of) the Oman and Somali upwelling areas. Wiggert et al. (2009) point out a contrasting biological response of the western Arabian Sea to the 1997/1998 and 2006/2007 events, with an overall decrease of productivity during the earlier and a slight increase during the latter. Negative chlorophyll and productivity anomalies in this region in 1997/1998 have been attributed to IOD (Sarma, 2006), although the co-occurrence of a strong El Niño did not allow the author to distinguish the impacts of the two climate 
modes. Our investigation suggests that the interannual variability in this region, including that of chlorophyll, is more strongly related to ENSO forcing than to IOD. These findings are supported by Kao and Yu (2009), who show evidence that El Niño events peaking in the eastern Pacific are related to northeasterly wind anomalies and warmer SST in the western Arabian Sea during June-September. Furthermore, Syroka and Toumi (2004) and Xavier et al. (2007) have shown evidence of a shortened summer monsoon linked to El Niño, which would imply a shorter period of active upwelling and likely less productivity in those years.

Due to opposing regional signals, the basin-scale Indian Ocean chlorophyll response to co-occurring events seems to be weak (Fig. 9), as pointed out by Wiggert et al. (2009). Extensive regional re-organisation does take place however, with significant integrated chlorophyll anomalies occurring over periods of several months in certain regions. As phytoplankton constitute the basal trophic level in pelagic environments, and by their ecology dictate the pathway of energy flow through the ecosystem (Falkowski et al., 1998), such climate-mode anomalies likely have great repercussions for pelagic ecosystems. The disruption of Indian Ocean ecosystems and resources has been attributed to ENSO/IOD events (e.g. Marsac and Le Blanc, 1999; Ménard et al., 2007; Spencer et al., 2000; Vialard et al., 2009), although the necessary biological data sets to detect such disruptions at higher trophic levels are often lacking. Through the coordinated effort of international research programs such as SIBER (Hood et al., 2010), by increasing the availability of higher resolution and longer-term data sets of physical, biogeochemical and biological variability, and with the use of rapidly progressing coupled ecosystem models to fill in the gaps, we have increasingly exciting and fruitful avenues available to understand and develop predictability of climate mode impacts on the physical and biological Indian Ocean.

\section{Supplementary material related to this article is available online at http://www.biogeosciences.net/10/ 6677/2013/bg-10-6677-2013-supplement.pdf.}

Acknowledgements. M. Lengaigne, J. Vialard, D. Kaplan, O. Aumont and O. Maury are funded by Institut de Recherche pour le Développement (IRD). M. Lengaigne, O. Aumont and O. Maury acknowledge the support of the French ANR, under the grant CEP MACROES (MACRoscope for Oceanic Earth System ANR-09CEP-003). M. Lengaigne and J. Vialard did part of this work as visiting scientists at the National Institute of Oceanography in Goa, India. IRD funding supported J. Currie throughout his masters degree, from which work this paper was borne, and supported a visit to NIO for him to work on this study with M. Lengaigne and J. Vialard. Thanks are due to Raghu Murtugudde and Marina Lévy for their incisive comments on the manuscript. Two anonymous reviewers are acknowledged for their detailed treatment of the paper, which improved the final product.

Edited by: R. Hood

\section{References}

Abram, N. J., Gagan, M. K., McCulloch, M. T., Chappell, J., and Hantoro, W. S.: Coral reef death during the 1997 Indian Ocean Dipole linked to Indonesian wildfires, Science, 301, 952-955, doi:10.1126/science.1083841, 2003.

Abram, N. J., Gagan, M. G., McCulloch, M. T., Chappell, J., and Hantoro, W. S.: Response to comment on "Coral reef death during the 1997 Indian Ocean Dipole linked to Indonesian wildfires", Science, 303, 1297-1297, doi:10.1126/science.1094047, 2004.

Annamalai, H., Murtugudde, R., Potemra, J., Xie, S. P., Liu, P., and Wang, B.: Coupled dynamics over the Indian Ocean: spring initiation of the Zonal Mode, Deep-Sea Res. Pt. II, 50, 2305-2330, doi:10.1016/S0967-0645(03)00058-4, 2003.

Aumont, O. and Bopp, L.: Globalizing results from ocean in situ iron fertilization studies, Global Biogeochem. Cy., 20, GB2017, doi:10.1029/2005GB002591, 2006.

Aumont, O., Bopp, L., and Schulz, M.: What does temporal variability in aeolian dust deposition contribute to sea-surface iron and chlorophyll distributions?, Geophys. Res. Lett., 35, L07607, doi:10.1029/2007GL031131, 2008.

Ballabrera-Poy, J., Murtugudde, R. G., Christian, J. R., and Busalacchi, A. J.: Signal-to-noise ratios of observed monthly tropical ocean color, Geophys. Res. Lett., 30, 1645, doi:10.1029/2003GL016995, 2003.

Baquero-Bernal, A., Latif, M., and Legutke, S.: On dipolelike variability of sea surface temperature in the tropical Indian Ocean, J. Climate, 15, 1358-1368, doi:10.1175/15200442(2002)015<1358:ODVOSS>2.0.CO;2, 2002.

Behrenfeld, M. J., Westberry, T. K., Boss, E. S., O'Malley, R. T., Siegel, D. A., Wiggert, J. D., Franz, B. A., McClain, C. R., Feldman, G. C., Doney, S. C., Moore, J. K., Dall'Olmo, G., Milligan, A. J., Lima, I., and Mahowald, N.: Satellite-detected fluorescence reveals global physiology of ocean phytoplankton, Biogeosciences, 6, 779-794, doi:10.5194/bg-6-779-2009, 2009.

Bjerknes, J.: Atmospheric teleconnections from the equatorial Pacific, Mon. Weather Rev., 97, 163-172, doi:10.1175/15200493(1969)097<0163:ATFTEP>2.3.CO;2, 1969.

Blanke, B. and Delecluse, P.: Variability of the tropical Atlantic Ocean simulated by a general circulation model with two different mixed-Layer physics, J. Phys. Oceanogr., 23, 1363-1388, doi:10.1175/1520-0485(1993)023<1363:VOTTAO>2.0.CO;2, 1993.

Boyer, T., Levitus, S., Garcia, H., Locarnini, R. A., Stephens, C., and Antonov, J.: Objective analyses of annual, seasonal, and monthly temperature and salinity for the World Ocean on a $0.25^{\circ}$ grid, Int. J. Climatol., 25, 931-945, doi:10.1002/joc.1173, 2005.

Claustre, H., Morel, A., Hooker, S. B., Babin, M., Antoine, D., Oubelkheir, K., Bricaud, A., Leblanc, K., Quéguiner, B., and Maritorena, S.: Is desert dust making oligotrophic waters greener?, Geophys. Res. Lett., 29, 107-1, doi:10.1029/2001GL014056, 2002.

Cleveland, R. B., Cleveland, W. S., McRae, J. E., and Terpenning, I.: STL: A seasonal-trend decomposition procedure based on loess, J. Official Statist., 6, 3-73, 1990.

Cravatte, S., Madec, G., Izumo, T., Menkes, C., and Bozec, A.: Progress in the 3-D circulation of the eastern equatorial $\mathrm{Pa}$ cific in a climate ocean model, Ocean Model., 17, 28-48, doi:10.1016/j.ocemod.2006.11.003, 2007. 
Dandonneau, Y., Vega, A., Loisel, H., Du Penhoat, Y., and Menkes, C.: Oceanic Rossby Waves acting as a "hay rake" for ecosystem floating by-products, Science, 302, 1548-1551, doi:10.1126/science.1090729, 2003.

Djavidnia, S., Mélin, F., and Hoepffner, N.: Comparison of global ocean colour data records, Ocean Sci., 6, 61-76, doi:10.5194/os6-61-2010, 2010.

Du, Y., Xie, S.-P., Huang, G., and Hu, K.: Role of airsea interaction in the long persistence of El Niño-induced north Indian Ocean warming, J. Climate, 22, 2023-2038, doi:10.1175/2008JCLI2590.1, 2009.

Falkowski, P. G., Barber, R. T., and Smetacek, V.: Biogeochemical controls and feedbacks on ocean primary production, Science, 281, 200-206, doi:10.1126/science.281.5374.200, 1998.

Feng, M. and Meyers, G.: Interannual variability in the tropical Indian Ocean: a two-year time-scale of Indian Ocean Dipole, Deep-Sea Res. Pt. II, 50, 2263-2284, doi:10.1016/S09670645(03)00056-0, 2003.

Geider, R. J., MacIntyre, H. L., and Kana, T. M.: A dynamic regulatory model of phytoplanktonic acclimation to light, nutrients, and temperature, Limnol. Oceanogr., 43, 679-694, 1998.

Goosse, H.: Modelling the large-scale behaviour of the coupled ocean-sea-ice system, Ph.D. thesis, Université catholique de Louvain, Belgium, 1997.

Gordon, H. R. and McCluney, W. R.: Estimation of the depth of sunlight penetration in the sea for remote sensing, Appl. Opt., 14, 413-416, 1975.

Hastenrath, S.: Dipoles, temperature gradients, and tropical climate anomalies, B. Am. Meteorol. Soc., 83, 735-738, doi:10.1175/1520-0477(2002)083<0735:WLACNM>2.3.CO;2, 2002.

Hermes, J. C. and Reason, C. J. C.: Annual cycle of the south Indian Ocean (Seychelles-Chagos) thermocline ridge in a regional ocean model, J. Geophys. Res.-Oceans, 113, C04035, doi:10.1029/2007JC004363, 2008.

Hood, R. R., Wiggert, J. D., and Naqvi, S. W. A.: A New Basinwide, International Program in the Indian Ocean, Ocean Carbon and Biogeochemistry News, 3, 5-8, 2010.

Horii, T., Hase, H., Ueki, I., and Masumoto, Y.: Oceanic precondition and evolution of the 2006 Indian Ocean dipole, Geophys. Res. Lett., 35, L03607, doi:10.1029/2007GL032464, 2008.

Howden, S. D. and Murtugudde, R.: Effects of river inputs into the Bay of Bengal, J. Geophys. Res.-Oceans, 106, 19825-19843, doi:10.1029/2000JC000656, 2001.

Iskandar, I., Rao, S., and Tozuka, T.: Chlorophyll-a bloom along the southern coasts of Java and Sumatra during 2006, Int. J. Remote. Sens., 30, 663-671, 2009.

Izumo, T., Vialard, J., Lengaigne, M., de Boyer Montégut, C., Behera, S. K., Luo, J.-J., Cravatte, S., Masson, S., and Yamagata, T.: Influence of the state of the Indian Ocean Dipole on the following year's El Niño, Nat. Geosci., 3, 168-172, doi:10.1038/ngeo760, 2010.

Jackett, D. R. and Mcdougall, T. J.: Minimal adjustment of hydrographic profiles to achieve static stability, J. Atmos. Ocean. Technol., 12, 381-389, doi:10.1175/15200426(1995)012<0381:MAOHPT>2.0.CO;2, 1995.

Kao, H.-Y. and Yu, J.-Y.: Contrasting eastern-Pacific and central-Pacific types of ENSO, J. Climate, 22, 615-632, doi:10.1175/2008JCLI2309.1, 2009.
Keerthi, M., Lengaigne, M., Vialard, J., de Boyer Montégut, C., and Muraleedharan, P.: Interannual variability of the Tropical Indian Ocean mixed layer depth, Clim. Dynam., 38, 1-17, doi:10.1007/s00382-012-1295-2, 2012.

Klein, S. A., Soden, B. J., and Lau, N. C.: Remote sea surface temperature variations during ENSO: Evidence for a tropical atmospheric bridge, J. Climate, 12, 917-932, doi:10.1175/15200442(1999)012<0917:RSSTVD>2.0.CO;2, 1999.

Koné, V., Aumont, O., Levy, C., and Resplandy, L.: Physical and biogeochemical controls of the phytoplankton seasonal cycle in the Indian Ocean: A modeling study, in: Indian Ocean Biogeochemical Processes and Ecological Variability, vol. 185, edited by: J. D. Wiggert, R. R. Hood, S. Wajih, A. Naqvi, K. H. Brink, and S. L. Smith, p. 350, 2009.

Lengaigne, M. and Vecchi, G.: Contrasting the termination of moderate and extreme El Niño events in coupled general circulation models, Clim. Dynam., 35, 299-313, doi:10.1007/s00382-0090562-3, 2010.

Lengaigne, M., Boulanger, J.-P., Menkes, C., Masson, S., Madec, G., and Delecluse, P.: Ocean response to the March 1997 Westerly Wind Event, J. Geophys. Res.-Oceans, 107, 8015, doi:10.1029/2001JC000841, 2002.

Lengaigne, M., Madec, G., Menkes, C., and Alory, G.: Impact of isopycnal mixing on the tropical ocean circulation, J. Geophys. Res.-Oceans, 108, 3345, doi:10.1029/2002JC001704, 2003.

Lengaigne, M., Boulanger, J.-P., Menkes, C., and Spencer, H.: Influence of the seasonal cycle on the termination of El Niño events in a coupled general circulation model, J. Climate, 19, 1850-1868, doi:10.1175/JCLI3706.1, 2006.

Lengaigne, M., Menkes, C., Aumont, O., Gorgues, T., Bopp, L., André, J.-M., and Madec, G.: Influence of the oceanic biology on the tropical Pacific climate in a coupled general circulation model, Clim. Dynam., 28, 503-516, doi:10.1007/s00382-0060200-2, 2007.

Lengaigne, M., Hausmann, U., Madec, G., Menkes, C., Vialard, J., and Molines, J.: Mechanisms controlling warm water volume interannual variations in the equatorial Pacific: diabatic versus adiabatic processes, Clim. Dynam., 38, 1031-1046, doi:10.1007/s00382-011-1051-z, 2012.

Lewis, M. R., Hebert, D., Harrison, W., Platt, T., and Oakey, N. S.: Vertical nitrate fluxes in the oligotrophic ocean, Science, 234, 870-873, 1986.

Madec, G., Delecluse, P., Imbard, M., and Lévy, C.: OPA 8.1 Ocean general circulation model reference manual, Note du Pôle de modélisation, IPSL, Paris, 1998.

Maritorena, S., D' Andon, O. H. F., Mangin, A., and Siegel, D. A.: Merged satellite ocean color data products using a bio-optical model: Characteristics, benefits and issues, Remote Sens. Environ., 114, 1791-1804, doi:10.1016/j.rse.2010.04.002, 2010.

Marsac, F. and Le Blanc, J. L.: Oceanographic changes during the 1997-1998 El Niño in the Indian Ocean and their impact on the purse seine fishery, IOTC Proceedings, 2, 147-157, 1999.

Maury, O.: An overview of APECOSM, a spatialized mass balanced "Apex Predators ECOSystem Model" to study physiologically structured tuna population dynamics in their ecosystem, Prog. Oceanogr., 84, 113-117, doi:10.1016/j.pocean.2009.09.013, 2010 . 
McClain, C. R., Signorini, S. R., and Christian, J. R.: Subtropical gyre variability observed by ocean-color satellites, Deep-Sea Res. Pt. II, 51, 281-301, doi:10.1016/j.dsr2.2003.08.002, 2004.

McPhaden, M. J., Zebiak, S. E., and Glantz, M. H.: ENSO as an Integrating Concept in Earth Science, Science, 314, 1740-1745, doi:10.1126/science.1132588, 2006.

Ménard, F., Marsac, F., Bellier, E., and Cazelles, B.: Climatic oscillations and tuna catch rates in the Indian Ocean: a wavelet approach to time series analysis, Fish. Oceanogr., 16, 95-104, doi:10.1111/j.1365-2419.2006.00415.x, 2007.

Messié, M. and Chavez, F. P.: A global analysis of ENSO synchrony: The oceans' biological response to physical forcing, J. Geophys. Res.-Oceans, 117, C09001, doi:10.1029/2012JC007938, 2012.

Meyers, G., McIntosh, P., Pigot, L., and Pook, M.: The Years of El Niño, La Niña, and interactions with the tropical Indian Ocean, J. Climate, 20, 2872-2880, doi:10.1175/JCLI4152.1, 2007.

Morel, A. and Maritorena, S.: Bio-optical properties of oceanic waters: A reappraisal, J. Geophys. Res.-Oceans, 106, 7163-7180, doi:10.1029/2000JC000319, 2001.

Morel, A., Huot, Y., Gentili, B., Werdell, P. J., Hooker, S. B., and Franz, B. A.: Examining the consistency of products derived from various ocean color sensors in open ocean (Case 1) waters in the perspective of a multi-sensor approach, Remote Sens. Environ., 111, 69-88, doi:10.1016/j.rse.2007.03.012, 2007.

Murtugudde, R. and Busalacchi, A. J.: Interannual variability of the dynamics and thermodynamics of the tropical Indian Ocean, J. Climate, 12, 2300-2326, doi:10.1175/15200442(1999)012<2300:IVOTDA>2.0.CO;2, 1999.

Murtugudde, R. G., Signorini, S. R., Christian, J. R., Busalacchi, A. J., McClain, C. R., and Picaut, J.: Ocean color variability of the tropical Indo-Pacific basin observed by SeaWiFS during 19971998, J. Geophys. Res.-Oceans, 104, 18351-18366, 1999.

Murtugudde, R., Wang, L., Hackert, E., Beauchamp, J., Christian, J., and Busalacchi, A. J.: Remote sensing of the IndoPacific region: ocean colour, sea level, winds and sea surface temperatures, Int. J. Remote. Sens., 25, 1423-1435, doi:10.1080/01431160310001592391, 2004.

Nidheesh, A. G., Lengaigne, M., Vialard, J., Unnikrishnan, A. S., and Dayan, H.: Decadal and long-term sea level variability in the tropical Indo-Pacific Ocean, Clim. Dynam., 41, 381-402, doi:10.1007/s00382-012-1463-4, 2013.

O'Reilly, J. E., Maritorena, S., Mitchell, B. G., Siegel, D. A., Carder, K. L., Garver, S. A., Kahru, M., and McClain, C.: Ocean color chlorophyll algorithms for SeaWiFS, J. Geophys. Res.Oceans, 103, 24937-24953, 1998.

Paulson, C. A. and Simpson, J. J.: Irradiance measurements in the upper ocean, J. Phys. Oceanogr., 7, 952-956, 1977.

Prasanna Kumar, S., Nuncio, M., Ramaiah, N., Sardesai, S., Narvekar, J., Fernandes, V., and Paul, J. T.: Eddy-mediated biological productivity in the Bay of Bengal during fall and spring intermonsoons, Deep-Sea Res. Pt. I, 54, 1619-1640, doi:10.1016/j.dsr.2007.06.002, 2007.

Prasanna Kumar, S., Nuncio, M., Narvekar, J., Ramaiah, N., Sardessai, S., Gauns, M., Fernandes, V., Paul, J. T., Jyothibabu, R., and Jayaraj, K. A.: Seasonal cycle of physical forcing and biological response in the Bay of Bengal, Indian J. Mar. Sci., 39, 388-405, 2010 .
R Development Core Team: R: A language and environment for statistical computing, Vienna, Austria, available at: http://www. R-project.org, 2011.

Rao, S. A. and Behera, S. K.: Subsurface influence on SST in the tropical Indian Ocean: structure and interannual variability, Dynam. Atmos. Oceans, 39, 103-135, doi:10.1016/j.dynatmoce.2004.10.014, 2005.

Rao, S. A., Behera, S. K., Masumoto, Y. and Yamagata, T.: Interannual subsurface variability in the tropical Indian Ocean with a special emphasis on the Indian Ocean Dipole, Deep-Sea Res. Pt. II, 49, 1549-1572, doi:10.1016/S0967-0645(01)00158-8, 2002.

Rao, R. R., Girish Kumar, M. S., Ravichandran, M., Rao, A. R., Gopalakrishna, V. V. and Thadathil, P.: Interannual variability of Kelvin wave propagation in the wave guides of the equatorial Indian Ocean, the coastal Bay of Bengal and the southeastern Arabian Sea during 1993-2006, Deep-Sea Res. Pt. I, 57, 1-13, doi:10.1016/j.dsr.2009.10.008, 2010.

Reason, C. J. C., Allan, R. J., Lindesay, J. A., and Ansell, T. J.: ENSO and climatic signals across the Indian Ocean Basin in the global context: Part I, interannual composite patterns, Int. J. Climatol., 20, 1285-1327, doi:10.1002/10970088(200009)20:11<1285::AID-JOC536>3.0.CO;2-R, 2000.

Reverdin, G., Cadet, D. L., and Gutzler, D.: Interannual displacements of convection and surface circulation over the equatorial Indian Ocean, Q. J. Roy. Meteor. Soc., 112, 43-67, doi:10.1002/qj.49711247104, 1986.

Rodgers, K. B., Aumont, O., Menkes, C., and Gorgues, T.: Decadal variations in equatorial Pacific ecosystems and ferrocline/pycnocline decoupling, Global Biogeochem. Cy., 22, GB2019, doi:10.1029/2006GB002919, 2008.

Saji, N. H., Goswami, B. N., Vinayachandran, P. N., and Yamagata, T.: A dipole mode in the tropical Indian Ocean, Nature, 401, 360363, 1999.

Sarma, V. V. S. S.: The influence of Indian Ocean Dipole (IOD) on biogeochemistry of carbon in the Arabian Sea during 1997-1998, J. Earth Syst. Sci., 115, 433-450, doi:10.1007/BF02702872, 2006.

Schott, F. A., Xie, S.-P., and McCreary, J. P.: Indian Ocean circulation and climate variability, Rev. Geophys., 47, RG1002, doi:10.1029/2007RG000245, 2009.

Song, Q., Vecchi, G. A., and Rosati, A. J.: Indian Ocean variability in the GFDL coupled climate model, J. Climate, 20, 2895-2916, doi:10.1175/JCLI4159.1, 2007.

Song, Q., Vecchi, G. A., and Rosati, A. J.: Predictability of the Indian Ocean sea surface temperature anomalies in the GFDL coupled model, Geophys. Res. Lett., 35, L02701, doi:10.1029/2007GL031966, 2008.

Spencer, T., Teleki, K. A., Bradshaw, C., and Spalding, M. D.: Coral Bleaching in the Southern Seychelles During the 19971998 Indian Ocean Warm Event, Mar. Pollut. Bull., 40, 569-586, doi:10.1016/S0025-326X(00)00026-6, 2000.

Sprintall, J. and Tomczak, M.: Evidence of the barrier layer in the surface layer of the tropics, J. Geophys. Res.-Oceans, 97, 73057316, doi:10.1029/92JC00407, 1992.

Susanto, R. D. and Marra, J.: Effects of the 1997/98 El Niño on chlorophyll a variability along the southern coasts of Java and Sumatra, Oceanography, 18, 124-127, 2005. 
Syroka, J. and Toumi, R.: On the withdrawal of the Indian summer monsoon, Q. J. Roy. Meteor. Soc., 130, 989-1008, doi:10.1256/qj.03.36, 2004.

Takahashi, T., Broecker, W. S., and Langer, S.: Redfield ratio based on chemical data from isopycnal surfaces, J. Geophys. Res.Oceans, 90, 6907-6924, doi:10.1029/JC090iC04p06907, 1985.

Thadathil, P., Muraleedharan, P. M., Rao, R. R., Somayajulu, Y. K., Reddy, G. V., and Revichandran, C.: Observed seasonal variability of barrier layer in the Bay of Bengal, J. Geophys. Res.Oceans, 112, C02009, doi:10.1029/2006JC003651, 2007.

Timmermann, R., Goosse, H., Madec, G., Fichefet, T., Ethe, C., and Dulière, V.: On the representation of high latitude processes in the ORCA-LIM global coupled sea ice-ocean model, Ocean Model., 8, 175-201, doi:10.1016/j.ocemod.2003.12.009, 2005.

Trenberth, K. E.: The definition of El Niño, B. Am. Meteorol. Soc., 78, 2771-2777, 1997.

Trenberth, K. E., Olson, J. G., Large, W. G.: A global ocean wind stress climatology based on ECMWF analyses, Climate and Global Dynamics Division, National Center for Atmospheric Research, Boulder, Colorado, 1989.

Uppala, S. M., KÅllberg, P. W., Simmons, A. J., Andrae, U., Bechtold, V. D. C., Fiorino, M., Gibson, J. K., Haseler, J., Hernandez, A., Kelly, G. A., Li, X., Onogi, K., Saarinen, S., Sokka, N., Allan, R., Andersson, E., Arpe, K., Balmaseda, M., Beljaars, A., van de Berg, L., Bidlot, J., Bormann, N., Caires, S., Chevallier, F., Dethof, A., Dragosavac, M., Fisher, M., Fuentes, M., Hagemann, S., Holm, E., Hoskins, B., Isaksen, L., Janssen, P., Jenne, R., McNally, A., Mahfouf, J.-F., Morcrette, J.-J., Rayner, N., Saunders, R., Simon, P., Sterl, A., Trenberth, K., Untch, A., Vasiljevic, D., Viterbo, P., and Woollen, J.: The ERA-40 re-analysis, Q. J. Roy. Meteor. Soc., 131, 2961-3012, 2005.

Van Woesik, R.: Comment on "Coral reef death during the 1997 Indian Ocean Dipole linked to Indonesian wildfires", Science, 303, 1297-1297, doi:10.1126/science.1091983, 2004.

Venzke, S., Latif, M., and Villwock, A.: Coupled GCM ECHO-2. Part II: Indian ocean response to ENSO, J. Climate, 13, 13711383, 2000.

Vialard, J., Menkes, C., Boulanger, J.-P., Delecluse, P., Guilyardi, E., McPhaden, M. J., and Madec, G.: A model study of oceanic mechanisms affecting equatorial Pacific sea surface temperature during the 1997-98 El Niño, J. Phys. Oceanogr., 31, 1649-1675, doi:10.1175/1520-0485(2001)031<1649:AMSOOM>2.0.CO;2, 2001.

Vialard, J., Duvel, J. P., Mcphaden, M. J., Bouruet-Aubertot, P., Ward, B., Key, E., Bourras, D., Weller, R., Minnett, P., Weill, A., Cassou, C., Eymard, L., Fristedt, T., Basdevant, C., Dandonneau, Y., Duteil, O., Izumo, T., de Boyer Montégut, C., Masson, S., Marsac, F., Menkes, C., and Kennan, S.: Cirene: Air-Sea Interactions in the Seychelles-Chagos Thermocline Ridge Region, B. Am. Meteorol. Soc., 90, 45-61, 2009.

Vinayachandran, P. N. and Mathew, S.: Phytoplankton bloom in the Bay of Bengal during the northeast monsoon and its intensification by cyclones, Geophys. Res. Lett., 30, 1572, doi:10.1029/2002GL016717, 2003.

Vinayachandran, P. N., Masumoto, Y., Mikawa, T., and Yamagata, T.: Intrusion of the Southwest Monsoon Current into the Bay of Bengal, J. Geophys. Res.-Oceans, 104, 11077-11085, doi:10.1029/1999JC900035, 1999.
Vinayachandran, P. N., Iizuka, S., and Yamagata, T.: Indian Ocean dipole mode events in an ocean general circulation model, Deep-Sea Res. Pt. II, 49, 1573-1596, doi:10.1016/S09670645(01)00157-6, 2002.

Vinueza, L. R., Branch, G. M., Branch, M. L., and Bustamante, R. H.: Top-down herbivory and bottom-up El Niño effects on Galápagos rocky-shore communities, Ecol. Monogr., 76, 111-131, doi:10.1890/04-1957, 2006.

Wang, C. and Fiedler, P. C.: ENSO variability and the eastern tropical Pacific: A review, Prog. Oceanogr., 69, 239-266, doi:10.1016/j.pocean.2006.03.004, 2006.

Webster, P. J., Moore, A. M., Loschnigg, J. P., and Leben, R. R.: Coupled ocean-atmosphere dynamics in the Indian Ocean during 1997-98, Nature, 401, 356-60, doi:10.1038/43848, 1999.

Wiggert, J. D. and Murtugudde, R. G.: The sensitivity of the southwest monsoon phytoplankton bloom to variations in aeolian iron deposition over the Arabian Sea, J. Geophys. Res.-Oceans, 112, C05005, doi:10.1029/2006JC003514, 2007.

Wiggert, J., Murtugudde, R., and McClain, C.: Processes controlling interannual variations in wintertime (Northeast Monsoon) primary productivity in the central Arabian Sea, Deep-Sea Res. Pt. II, 49, 2319-2343, doi:10.1016/S0967-0645(02)00039$5,2002$.

Wiggert, J. D., Hood, R. R., Banse, K., and Kindle, J. C.: Monsoondriven biogeochemical processes in the Arabian Sea, Prog. Oceanogr., 65, 176-213, doi:10.1016/j.pocean.2005.03.008, 2005.

Wiggert, J. D., Murtugudde, R. G., and Christian, J. R.: Annual ecosystem variability in the tropical Indian Ocean: Results of a coupled bio-physical ocean general circulation model, Deep-Sea Res. Pt. II, 53, 644-676, doi:10.1016/j.dsr2.2006.01.027, 2006.

Wiggert, J. D., Vialard, J., and Behrenfeld, M. J.: Basinwide modification of dynamical and biogeochemical processes by the positive phase of the Indian Ocean Dipole during the SeaWiFS era, in: Indian Ocean Biogeochemical Processes and Ecological Variability, vol. 185, edited by: J. D. Wiggert, R. R. Hood, S. Wajih, A. Naqvi, K. H. Brink, and S. L. Smith, p. 350, 2009.

Wilson, C. and Adamec, D.: A global view of bio-physical coupling from SeaWiFS and TOPEX satellite data, 1997-2001, Geophys. Res. Lett., 29, 1257, doi:10.1029/2001GL014063, 2002.

Xavier, P. K., Marzin, C., and Goswami, B. N.: An objective definition of the Indian summer monsoon season and a new perspective on the ENSO-monsoon relationship, Q. J. Roy. Meteor. Soc., 133, 749-764, doi:10.1002/qj.45, 2007.

Xie, P. and Arkin, P. A.: Global precipitation: A 17-year monthly analysis based on gauge observations, satellite estimates, and numerical model outputs, B. Am. Meteorol. Soc., 78, 2539-2558, 1997.

Xie, S. P., Annamalai, H., Schott, F. A., and McCreary, J. P.: Structure and mechanisms of south Indian Ocean climate variability, J. Climate, 15, 864-878, doi:10.1175/15200442(2002)015<0864:SAMOSI>2.0.CO;2, 2002.

Xie, S. P., Hafner, J., Tokinaga, H., Du, Y., Sampe, T., and Hu KaiMing, H. G.: Indian Ocean capacitor effect on Indo-western Pacific climate during the summer following El Niño, J. Climate, 22, 730-747, doi:10.1175/2008JCLI2544.1, 2009.

Yamagata, T., Behera, S. K., Luo, J. J., Masson, S., Jury, M. R., and Rao, S. A.: Coupled ocean-atmosphere variability in the 
tropical Indian Ocean, Geoph. Monog. Series, 147, 189-211, doi:10.1029/147GM12, 2004.

Yoder, J. A. and Kennelly, M. A.: Seasonal and ENSO variability in global ocean phytoplankton chlorophyll derived from 4 years of SeaWiFS measurements, Global Biogeochem. Cy., 17, 1112, doi:10.1029/2002GB001942, 2003.

Yokoi, T., Tozuka, T., and Yamagata, T.: Seasonal Variation of the Seychelles Dome, J. Climate, 21, 3740-3754, doi:10.1175/2008JCLI1957.1, 2008.
Yu, W., Xiang, B., Liu, L., and Liu, N.: Understanding the origins of interannual thermocline variations in the tropical Indian Ocean, Geophys. Res. Lett., 32, 24706, doi:10.1029/2005GL024327, 2005.

Zhang, Y., Rossow, W. B., Lacis, A. A., Oinas, V., and Mishchenko, M. I.: Calculation of radiative fluxes from the surface to top of atmosphere based on ISCCP and other global data sets: Refinements of the radiative transfer model and the input data, J. Geophys. Res.-Atmos., 109, 19105, doi:10.1029/2003JD004457, 2004. 